\title{
ARIEL LEVY
}

\section{Elastografia e TRECs: Contribuição para a avaliação}

morfológica e funcional do timo em crianças de baixa idade

Dissertação apresentada à Faculdade de Medicina da Universidade de São Paulo para obtenção de título de Mestre em Ciências

Programa de Pediatria Orientadora: Prof. Dra. Magda Maria Sales Carneiro-Sampaio 
Dados Internacionais de Catalogaçăo na Publicaçăo (CIP)

Preparada pela Biblioteca da

Faculdade de Medicina da Universidade de Säo Paulo

Creproduçāo autorizada pelo autor

Levy, Ariel

Elastografia e TRECs : contribuiçäo para a

avaliaçấo morfologica e funcional do timo em erianças

de baixa idade/Ariel Levy. -. Săo Paulo, 2018.

Dissertaçâlo (mestrado)--Faculdade de Medicina da

Universidade de Săo Paulo.

Programa de Pediatria.

Orientador: Magda Maria Sales Carneiro Sampaio.

Descritores: 1.Timo 2. Lactente 3.Tecnicas de imagem por elastieidade 4. Ultrasson 5. Cireulos de excisalo do receptor de celula T 6.Iinfócitos T

7 , Receptores de antigenos de linfocitos T 8, Rearranjo gênico do linfóct to I

USP/FM/DBD $-447 / 18$

Responsàvel: Erinalva da Conceiçâo Batista, CRB-8 6755 
Aos meus pais, Alain e Liliane, pelo apoio incondicional dado a cada passo da minha vida

À minha amada esposa, Renata, por gerir e nutrir nossa família com amor.

Aos meus filhos, Gabriel e David, simplesmente por existirem. 


\section{Agradecimentos}

À Dra. Cristina M Jacob, que idealizou a tese e me incentivou a realizá-la

À Dra. Magda, pela paciência em me orientar

À Fabiana Agena, pelo apoio técnico em toda tese

À Dra Lisa Suzuki pela parte radiológica da tese

À Andréia Rangel e à equipe do LIM 36 por todo apoio molecular

Agradeço à FAPESP pelo custeio dos reagentes para realização dos TRECs e do elastógrafo para este projeto. 


\section{Normatização adotada}

Esta tese está de acordo com as seguintes normas, em vigor no momento desta publicação:

Referências: adaptado de International Committee of Medical Journals Editors (Vancouver).

Universidade de São Paulo. Faculdade de Medicina. Serviço de Biblioteca e Documentação. Guia de apresentação de dissertações, teses e monografias. Elaborado por Anneliese Carneiro da Cunha, Maria Julia de A. L. Freddi, Maria F. Crestana, Marinalva de Souza Aragão, Suely Campos Cardoso, Valéria Vilhena. $3^{a}$ edição. São Paulo: Serviço de Biblioteca e Documentação; 2011.

Abreviaturas dos títulos dos periódicos de acordo com List of Journals Indexed in Index Medicus. 


\section{SUMÁRIO}

Lista de abreviaturas e siglas

Lista de Figuras

Lista de Quadros

Lista de Tabelas

Resumo

Abstract

1. INTRODUÇÃO .................................................................................... 1

1.1 Função Tímica ............................................................................. 6

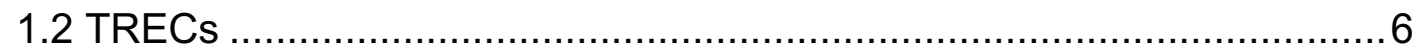

1.3 Marcação de subpopulações de linfócitos T por citometria de fluxo ......8

1.4 Avaliação imagenológica das dimensões tímicas ............................8

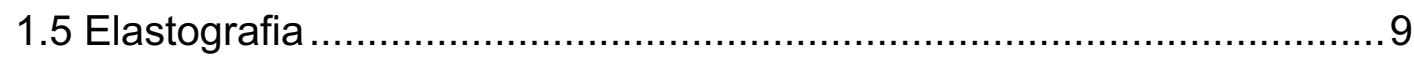

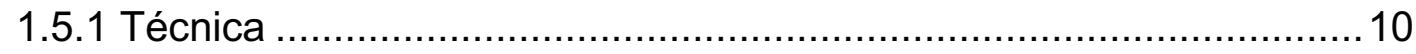

1.5.1.1 Elastografia por Tensão (Strain Elastography) ............................ 10

1.5.1.2- Elastografia por Tensão com utilização de ARFI .........................11

1.5.1.3 Elastografia por ondas de Cisalhamento (SWE) ....................... 11

1.5.1.4 Elastrografia por ondas de cisalhamento transitória..................... 12

1.5.1.5 Elastrografia por ondas de cisalhamento por ARFI ....................... 12

1.5.2 Aplicações clínicas ............................................................ 13

1.5.3 Limitações..................................................................... 14

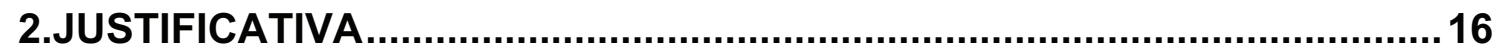

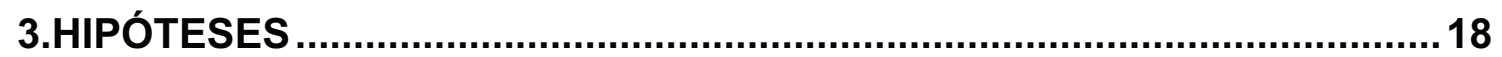

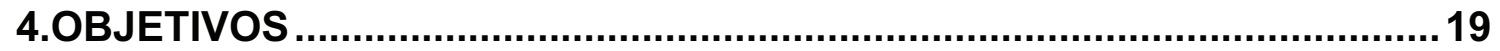

5. ASPECTOS ÉTICOS …......................................................................... 22

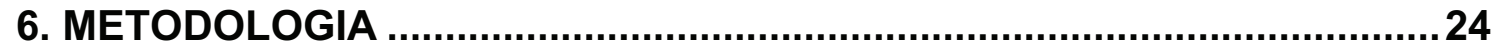

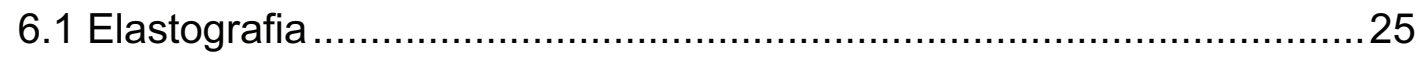

6.2. Quantificação do número de cópias de TREC em sangue total ..........27 


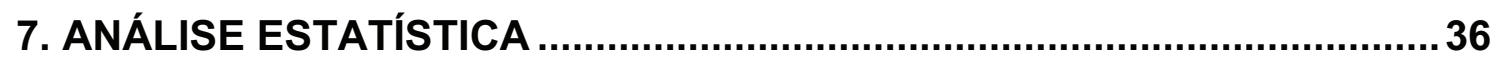

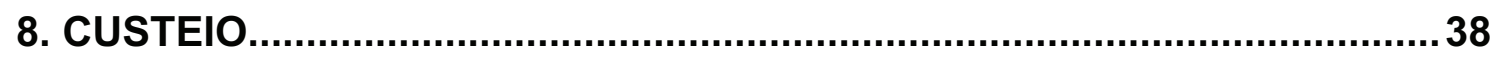

9. RESULTADOS

9.1. Análise dos parâmetros elastográficos ............................................. 41

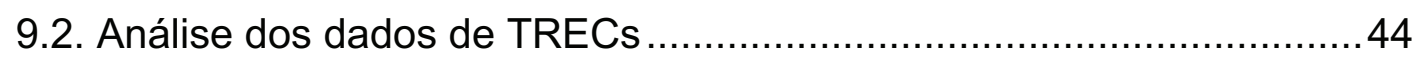

9.3.Análise comparativa do perfil elastográfico e TRECs...........................46

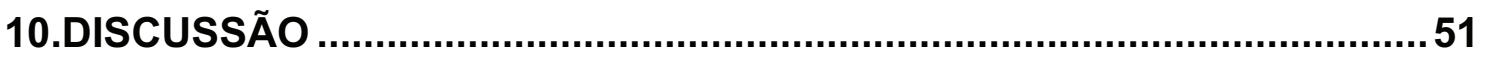

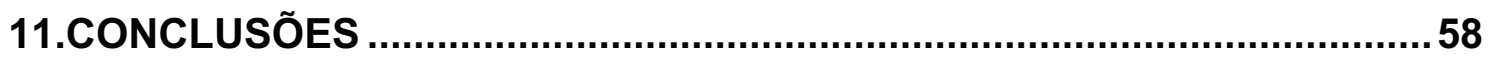

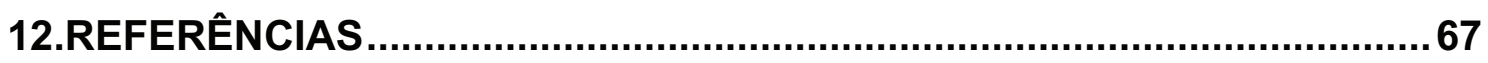




\section{LISTA DE ABREVIATURAS E SIGLAS}

ARFI Acoustic Radiation Force Impulse - impulso de força de radiação acústica

DN Duplo Negativo

kPA Kilo Pascal

MHC molécula de histocompatibilidade

$\mathrm{m} / \mathrm{s} \quad$ metro por segundo

ROI Region of Interest - região de interesse

SCID Imunodeficiência Combinada Grave

SDG Síndrome de Di Giorge

SWE Shear waves elastography - elastografia por ondas de cisalhamento

TC Tomografia computadorizada

TCR T cell receptor

TRECs $T$ cell receptor excision circles 


\section{LISTA DE FIGURAS}

Figura 1 Localização anatômica do timo.

Figura 2 Apresentação Histológica do Timo em HE. 3

Figura 3 Conformação do TCR em 2D e em 3D. 4

Figura 4 Saída de linfócitos da medula para o timo e neste as seleções positivas e negativas.

Figura 5 Quebra de DNA na posição em 3' e 5', seleção de genes e formação dos sj-TRECs e posteriormente dos cjTRECs... 7

Figura 6 Elastografia por Tensão. 10

Figura 7 Imagem de elastografia de timo mostrando tela com IQR de $27 \%$

Figura 8 Curvas de amplificação das diferentes diluições de TREC (I)

Figura 9 Curvas de amplificação das diferentes diluições de TREC (II)

Figura 10 Fluxograma de inclusão. 
Figura 11 Distribuição dos parâmetros da elastografia $(\mathrm{kPa})$ por faixa etária (box-plot).

Figura 12 Distribuição dos parâmetros da elastografia $(\mathrm{m} / \mathrm{s})$ por faixa etária

Figura 13 Distribuição dos números de TRECs (cópias $/ \mu L$ ) por faixa etária (Box-plot)

Figura 14 Correlação entre volume de timo e número de TRECs (sangue total)

Figura 15 Correlação de Spearman entre elastografia $(\mathrm{m} / \mathrm{s})$ e número de TRECs (sangue total)

Figura 16 Correlação de Spearman entre elastografia em kPa e número de TRECs (sangue total)

Figura 17 Correlação de Spearman entre elastografia em kPa e entre volume do timo e idade (meses)

Figura 18 Comparação de TRECs entre subgrupos $0-24 \mathrm{~m}$ e $25-60 \mathrm{~m}$ com os controles de 10 a 20 anos.

Figura 19 Correlação de Spearman entre idade e TRECs (sangue total). 


\section{LISTA DE QUADROS}

Quadro 1. Tipos de elastografia.

Quadro 2. Sequencias de Referências dos oligonucletídeos e sondas...... 


\section{LISTA DE TABELAS}

Tabela 1 Características demográficas e histórico gestacional (Grupo elastografia).

Tabela 2 Distribuição dos parâmetros da elastografia $(\mathrm{kPa})$ por faixa etária.

Tabela 3 Distribuição dos parâmetros da elastografia $(\mathrm{m} / \mathrm{s})$ por faixa etária.

Tabela 4 Características demográficas e histórico gestacional (Grupo TRECs).

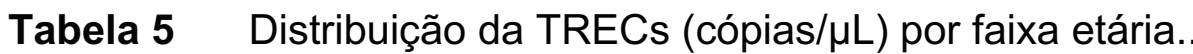
45

Tabela 6 Perfil elastográfico e TRECs da população estudada. 46 
RESUMO

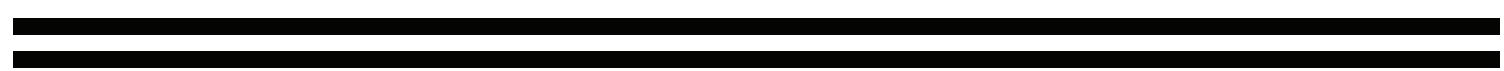


Levy A. Elastografia e TRECs: contribuição para a avaliação do timo em crianças de baixa idade [dissertação]. São Paulo: Faculdade de Medicina, Universidade de São Paulo; 2018.

O timo é um órgão linfoide primário, localizado em região mediastinal, cuja importância funcional é a diferenciação e maturação de todas as subpopulações de linfócitos $T$ provenientes da medula óssea assim como a seleção de células autorreativas. Sua hipoplasia ou aplasia resultam em síndromes de imunodeficiência. Embora de vital importância, o estudo clínico de sua função não é rotineiro na prática clínica, o que pode ser atribuído a sua dificuldade de avaliação em razão de sua localização, necessidade de uso de métodos de imagem não inócuos ao paciente (tomografia computadorizada (TC), PET-SCAN) e complexidade das análises em sangue periférico de subpopulações de células $T$ por citometria de fluxo e, mais recentemente, medição de $T$ cell receptor excision circles (TRECs), por PCR. Um possível método da avaliação do timo sem radiação ionizante ou dor ao paciente seria a elastografia de timo por ultrassom e seu uso na prática clínica poderia substituir a TC, como ocorre na avaliação de lesões hepáticas ou mamárias. Objetivo Este estudo se propõe a 1. Implantar este método na avaliação da função tímica, 2. Estabelecer valores de referência de TRECs na faixa etária estudada 3. Investigar se há correlação entre os dois parâmetros. Métodos - Foram incluídas sessenta e quatro crianças de $0-5$ anos em acompanhamento no ambulatório de cirurgia infantil sem doença sistêmica ou infecção aguda, e que iriam coletar amostra de sangue para exames pré-operatórios. Quarenta e oito destas coletaram amostra de sangue para avaliação de TRECs, vinte e nove realizaram elastografia num mesmo momento, porém apenas 13 destas apresentaram resultado confiável. A média da idade foi de $36 \pm 16$ meses, predomínio do grupo foi masculino $(75 \%)$, nascidos a termo $(72 \%)$ e a principal intervenção cirúrgica foi do tipo urológica de pequeno porte. A elastografia mostrou média de $1,21 \pm 0,24 \mathrm{~m} / \mathrm{s}$, sem diferença significativa quando comparada ano a ano. Observamos uma média de TRECs de 195,6 \pm 120,5 cópias $/ \mu \mathrm{L}$, mostrando valores significativamente mais altos quando comparados a adolescentes hígidos da base de dados do laboratório. Os valores de TRECs observados mostram uma ampla variabilidade na faixa etária estudada, sem diferença significativa quando separados por idade ano a ano. Não se encontrou correlação significativa entre a dureza do timo analisada à elastografia e valores de TRECs em sangue periférico. Concluímos que a elastografia é um método que possibilita a avaliação das dimensões e função do timo em crianças a partir de 2 anos de idade, entretanto estudos adicionais são necessários para que se possa recomendar a larga implantação deste método com essa finalidade.

Descritores: timo; lactente; técnicas de imagem por elasticidade; ultrassom; círculos de excisão do receptor de célula $\mathrm{T}$; linfócitos $\mathrm{T}$; receptores de antígenos de linfócitos $T$; rearranjo gênico do linfócito $T$. 
ABSTRACT

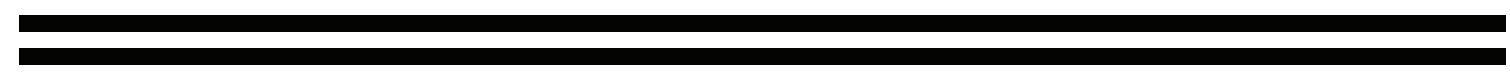


Levy A. Elastography and TRECs: contribution to the analysis of the thymic function in healthy children [dissertation]. São Paulo: "Faculdade de Medicina, Universidade de São Paulo"; 2018.

The thymus is a primary lymphoid gland responsible for the maturation of $T$ cells as well as the immunological central tolerance. It has been a neglected organ by physicians, despite its relevance in early immunity. Thymic function can be indirectly measured by Computerized Tomography imaging and PET SCAN, T cell subpopulation flow cytometry. More recently, in the beginning of this century, a direct measurement represented by TRECs ( $T$ cell receptors excision circles) was developed. Classical thymic imaging has used ionized radiation, which poses a major risk for the pediatric patient and new techniques are needed. Objectives and methods - In this work, we tested the use of elastography ultrasound for the evaluation of the thymus in a group of $<5$-yearold healthy children. In parallel, we measured TRECs in peripheral blood and compared the values obtained from both methods. We have reached sixty-four children at the pediatric surgery outpatients ambulatory, scheduled for minor surgeries. A sample of blood was taken during pre operatory and then patients were sent to the imaging service for elastography. Of all, sixty-four had undertaken TRECs and seventeen, elastography. The median age was $36 \pm 16$ months and we had $75 \%$ of boys for surgical correction of urologic minor defects. The elastography results showed a median of $1.2 \pm 0.24 \mathrm{~m} / \mathrm{s}$ in all ages, the same stiffness as the liver, as shown in other works. Our median TREC/ $\mu \mathrm{L}$ value was $195.6 \pm 120.5 \mathrm{copies} / \mu \mathrm{L}$ showing a trend of reduction in older ages, and with statistical significance when compared with healthy teenagers' values from the lab database. We concluded that elastography may be a good diagnostic tool for thymus evaluation, and additional works are needed for its recommendation in clinical practice. Our TRECs values showed a large variability, as also demonstrated in previous works, and a trend of reduction over age. We could not observe any significant correlation between elastography and TRECs values.

Descriptors: thymus gland; infant; elasticity imaging techniques; ultrassonics; T cell receptor excision circles; T-lymphocytes; receptors - antigen T-cell; gene rearrangement T-lymphocyte. 


\section{INTRODUÇÃO}

O timo é um órgão do sistema imunológico, cuja importância tem sido cada vez mais reconhecida. Localizado na região mediastinal, limita-se superiormente com a traqueia, a veia jugular interna e artéria carótida comum, lateralmente com os pulmões e póstero-inferiormente com o coração (Figura 1).

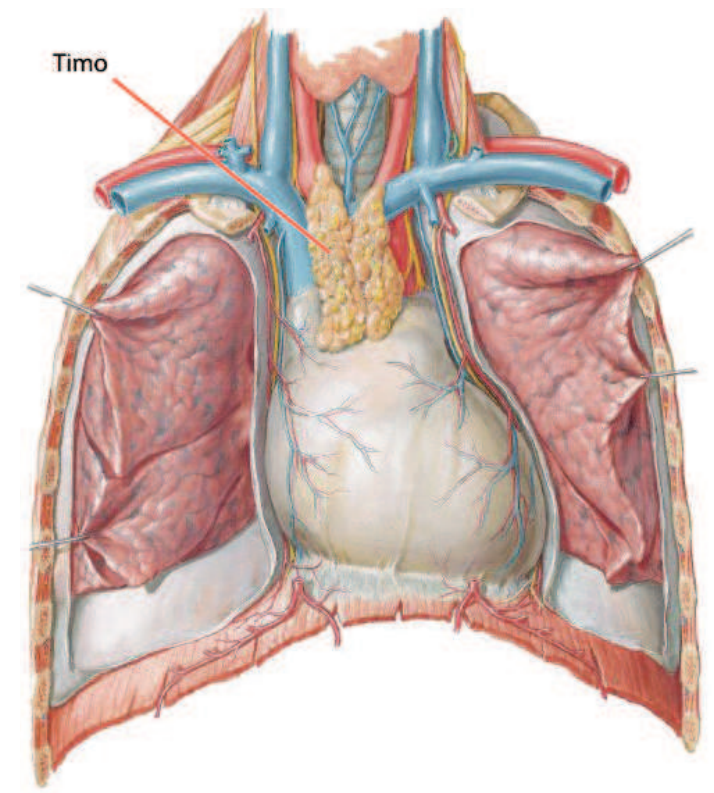

Figura 1 - Localização anatômica do timo ${ }^{1}$

Do ponto de vista funcional, é caracterizado como um órgão primário no desenvolvimento da resposta imune, responsável pela maturação dos linfócitos T. Possui importante função na resposta celular T-dependente, como demonstrado em doenças associadas à sua aplasia, a exemplo da Síndrome de DiGeorge (SDG) ou à sua hipoplasia e ao seu não desenvolvimento, como em grande parte das apresentações da Imunodeficiência Combinada Grave $(\mathrm{SCID})^{2}$. Dentre suas principais funções, o timo é responsável em fornecer o microambiente necessário para a maturação de progenitores linfóides oriundos da medula óssea até o estágio de linfócitos $T$, selecionar os linfócitos não reativos a antígenos próprios para serem liberados na circulação sistêmica, e 
promover a eliminação em seu interior daqueles autorreativos, que poderiam propiciar o desenvolvimento de autoimunidade ${ }^{3}$.

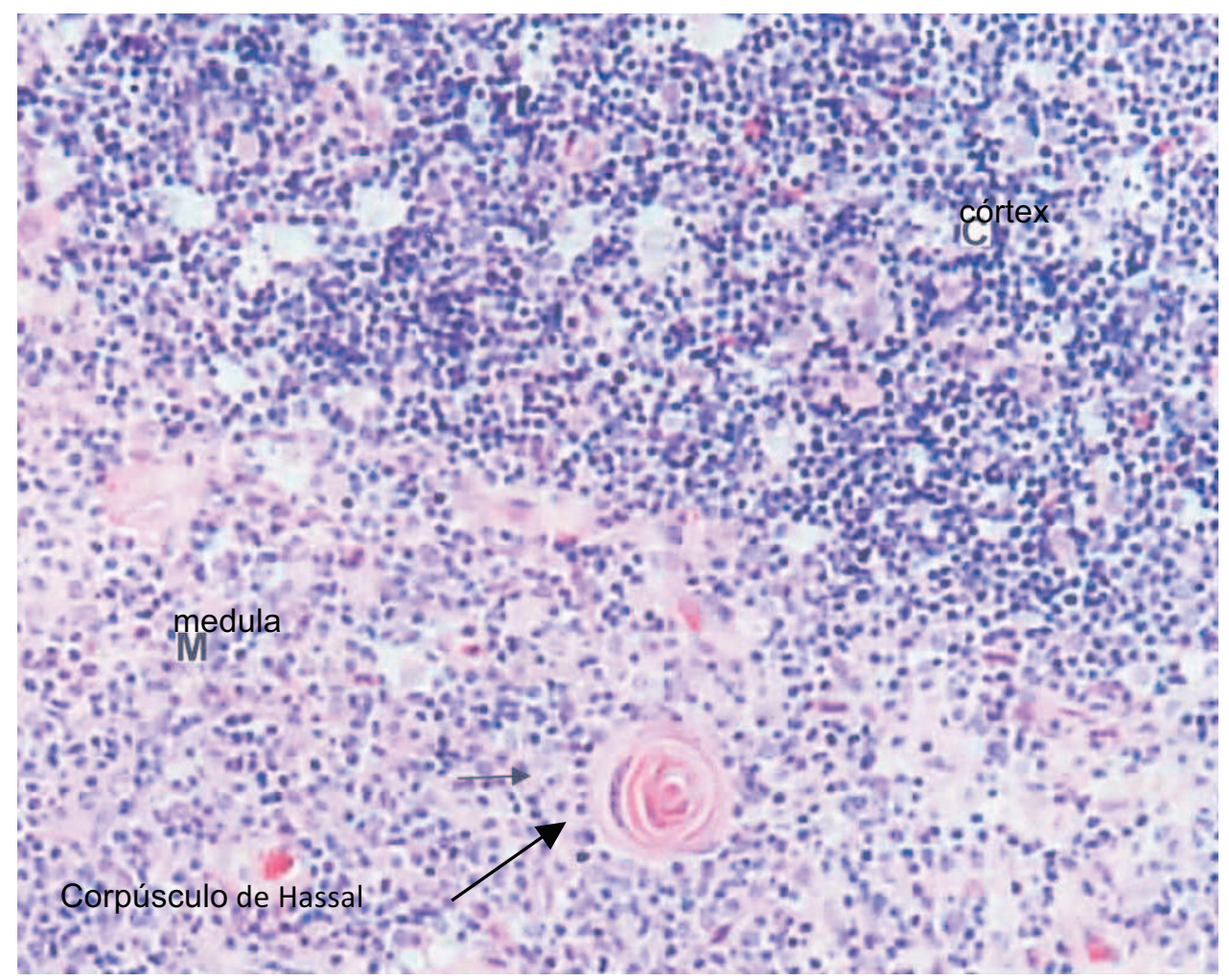

Figura 2 - Apresentação histológica de um Timo de lactente em $\mathrm{HE}^{4}$

A resposta imune adaptativa pode ser, didaticamente, separada em resposta imune celular (dependente dos linfócitos T) e humoral (dependente dos linfócitos $B)^{5}$. Esta última foi a primeira a ser estudada pois, seu principal produto, os anticorpos, eram facilmente separados do soro do paciente e quantificados por diversas técnicas laboratoriais. Apresentavam também a propriedade de poderem ser armazenados, mantendo a atividade biológica.

A imunidade celular, que é extremamente importante na defesa contra microrganismos intracelulares e controle da regulação imunológica, demandou técnicas mais avançadas para sua investigação clínica, tais como a identificação de marcadores da linhagem T e suas subpopulações, a cultura de linfócitos e o esclarecimento das diversas ativações de vias metabólicas celulares. Por essa razão, é menos estudada em relação àquela, e por isso, 
suscita mais pesquisas, em especial aquelas relacionadas à função tímica, que até recentemente era pouco discutida ${ }^{6}$.

O timo é responsável pelo microambiente formador de todas as subpopulações de linfócitos T. Estas são originadas a partir de células precursoras oriundas da medula óssea. Estas células são submetidas a um processo que envolve expressões sequenciais de várias proteínas e rearranjos aleatórios de receptores de células T (TCR). Esta enorme diversidade é necessária para fornecer a proteção contra diferentes agentes infecciosos, contra os quais o organismo defronta-se ao longo da vida; e também para que não ocorra reação contra elementos do próprio organismo ${ }^{7}$.

\section{Diversidade de receptores de linfócitos T}

- Estrutura do TcR (exemplo com $\alpha \beta$, mas também pode ser $\gamma \delta$ )

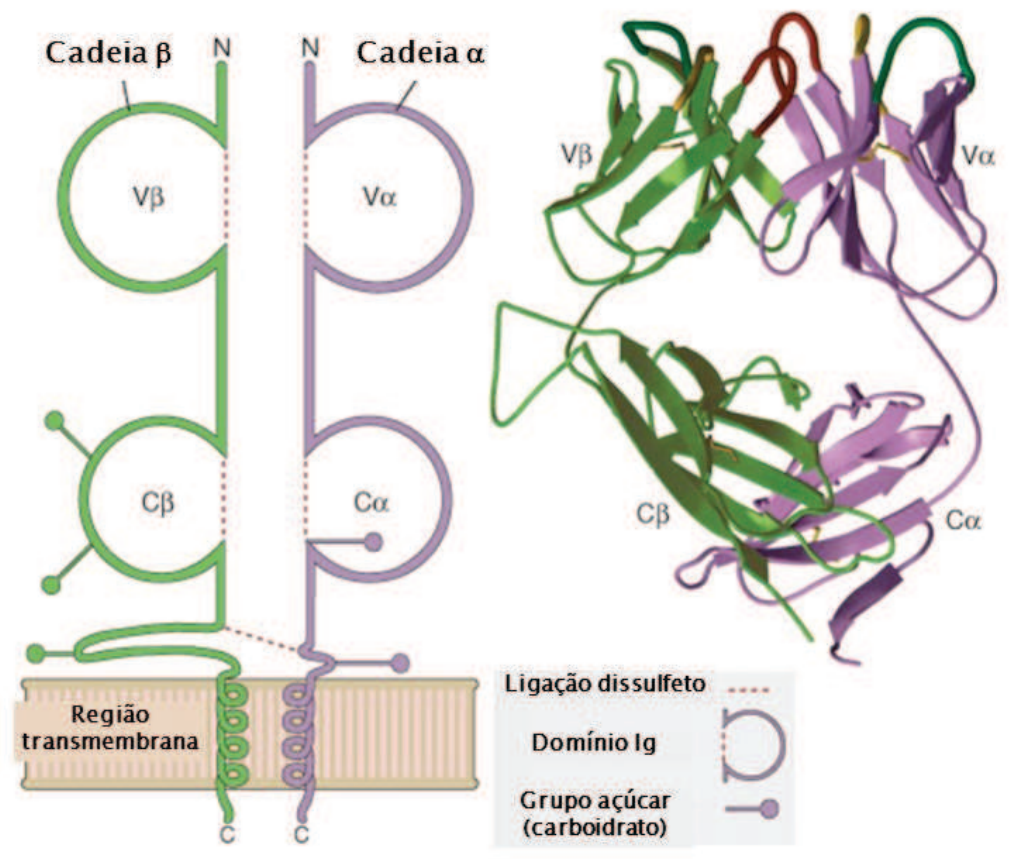

Figura 3 - Conformação do TCR em 2D e em 3D

Os timócitos mais imaturos não expressam as moléculas CD4 e CD8 (CD4-CD8-) e, por esta razão, são chamados de duplo-negativos (DN). Após o rearranjo de expressões de TCR, os timócitos se dividem rapidamente e 
adquirem marcadores CD4 e CD8. Essas células vão interagir com moléculas do complexo maior de histocompatibilidade (MHC), presentes no microambiente tímico. Timócitos que apresentam receptores com afinidade para antígenos próprios sofrem apoptose, num mecanismo de autotolerância (seleção positiva). Timócitos submetidos à seleção positiva passam a expressar somente CD4+ ou CD8+ a depender de sua ligação de baixa afinidade com MHC classe II ou I, respectivamente. Ainda no timo, após a seleção positiva, os linfócitos são apresentados a auto-antígenos. Aqueles linfócitos com alta afinidade aos auto-antígenos são eliminados por apoptose, processo ao qual chamamos de seleção negativa ${ }^{8}$.

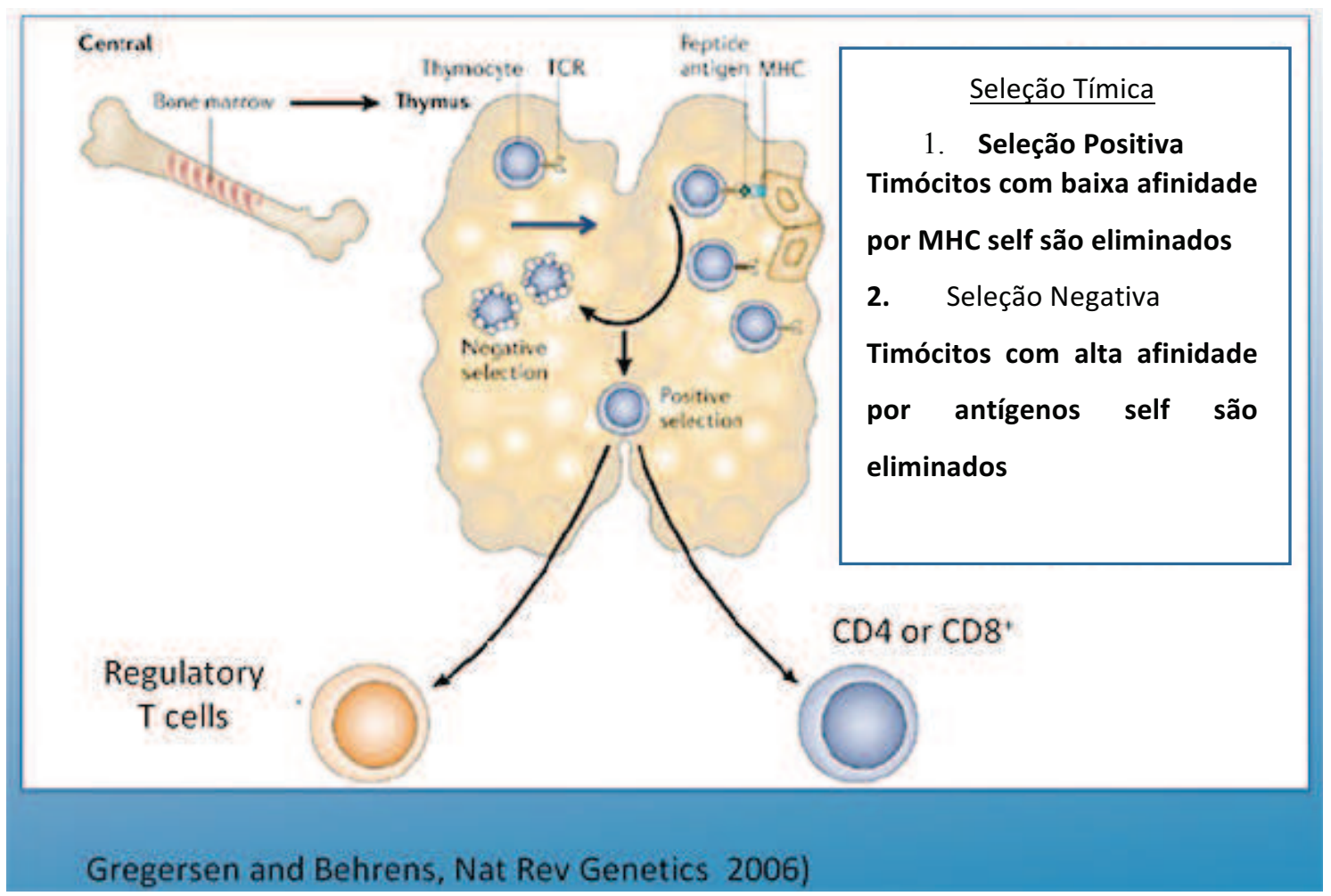

Figura 4 - Saída de linfócitos da medula para o timo e neste as seleções positivas e negativas $^{9}$ 


\subsection{Função Tímica}

A avaliação da função tímica é essencial na investigação de imunodeficiências ou de situações de imunodesrregulação. Atualmente as formas de avaliação consistem em medir TRECs (T cell receptor excision circles), que se encontram exclusivamente em linfócitos T recém emigrados do timo, contagem do número de linfócitos $T$ e suas subpopulações, através da citometria de fluxo com marcação de receptores de superfície, para além de métodos de imagem abaixo explanados ${ }^{10}$.

\subsection{TRECS}

Resultam no rearranjo para formar o TCR (T cell receptor), na qual há clivagem das porções VDJ que são formados os TRECs (T-cell receptor excision circles). Resultam da junção da ponta 3' com a 5' de uma clivagem necessária para o rearranjo do DNA, para formação da diversidade dos TCRs. Como os TRECs são formados apenas quando da formação de uma nova célula $T$, seu número corresponde apenas às células recém emigradas do timo. Quando os linfócitos T se multiplicam fora do timo ao encontrarem o antígeno, não ocorre duplicação de TRECs ${ }^{11-14}$. 


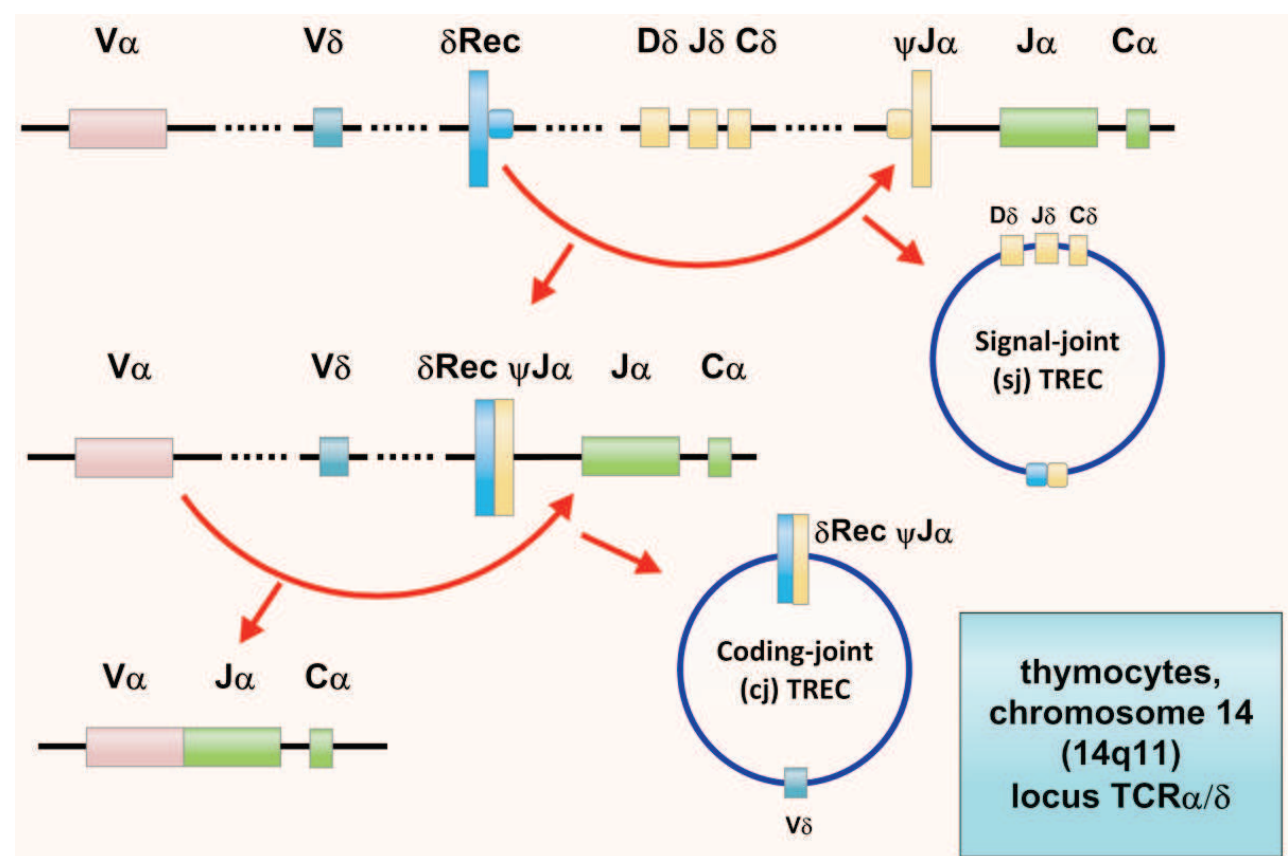

Figura 5- Quebra de DNA na posição em 3' e 5', seleção de genes e formação dos sj-TRECs e posteriormente dos cj-TRECs ${ }^{15}$

Assim, a avaliação das concentrações de TRECs em sangue periférico é um marcador do número de células recém emigradas do timo e, indiretamente, da função tímica.

Os TRECs fornecem valiosa informação do status do timo no momento da coleta. E comprovam tese morfológica de involução tímica por substituição gordurosa ${ }^{16} \mathrm{com}$ a queda de TRECs por idade, já iniciando nos primeiros anos de vida ${ }^{17}$. Algumas doenças como imunodeficiências primárias e adquiridas também diminuem o número de TRECs/ $\mu \mathrm{L}$ de sangue ${ }^{17}$, assim como na síndrome de Down ${ }^{18}$.

Os TRECs são utilizados atualmente na prática clínica quando da coleta do teste do pezinho para triagem de imunodeficiências, para averiguação de imunoreconstituição no paciente com AIDS em terapia antirretroviral e para avaliação de sucesso no transplante de medula óssea ${ }^{19-21}$. 


\subsection{Marcação de subpopulações de linfócitos $T$ por citometria de fluxo}

A citometria de fluxo identifica células com determinados marcadores, e assim, avalia a porcentagem de linfócitos $T$ näive que refletem as células recém emigradas do timo. O linfócito $\mathrm{T}$ näive tem os marcadores de membrana CD45RA e CD62L enquanto as células CD4+ ou CD8+ de memória tem CD45RO+ e CD62L. Com essas marcações de linfócitos à citometria de fluxo, portanto, pode-se estimar a função tímica.Os números de linfócitos CD3+, CD3+CD4+ e CD3+CD8+ representam um reflexo da atividade tímica e são o meio mais facilmente disponível de fazê-lo ${ }^{22}$.

\subsection{Avaliação imagenológica das dimensões tímicas}

O timo tem seu máximo peso relativo ao nascimento e atinge seu maior tamanho entre dez e quinze anos de idade ${ }^{23}$. Não há, até o momento, curva normal do tamanho, volume ou peso do timo por idade, sexo ou peso. Estudos mostram que a variação da morfologia tímica dependente dos fatores supracitados assim como antecedente étnico, aleitamento materno, estado nutricional, além de estado vacinal e histórico infeccioso entre outros ${ }^{24,} 25$. Embora a ultrassonografia tenha boa correlação com dados post mortem do peso do timo de crianças $^{24}$, o simples dado de tamanho e volume, não tem correlação com a função tímica e, portanto, a ultrassonografia não é um exame utilizado na avaliação do mesmo ${ }^{26,27}$.

Existem dois métodos já consagrados na avaliação indireta da função tímica: a tomografia computadorizada ${ }^{28-30}$, além do PET SCAN $^{10}$,este último mais usado para controle de tecido tímico em síndromes linfoproliferativas. 
Diferente da ultrassonografia, a tomografia computadorizada (TC) de timo tem a possibilidade de aferir indiretamente sua densidade ${ }^{28}$ que tem correlação com sua função. Porém, a TC é um método radiológico com alto grau de radiação ionizante, caro e por vezes se faz necessário o uso de anestesia, tornando o método pouco viável e anti-ético para o uso rotineiro.

\subsection{Elastografia}

A elastografia por ultra-sonografia é um método não invasivo que é capaz de inferir a rigidez do tecido de um órgão ou de uma lesão, através do grau de deformação ou da velocidade da onda que atravessa o mesmo. Sua primeira descrição ocorreu em 1990 por Ophir e colaboradores ${ }^{31}$, onde se usou uma pressão constante sobre a pele e mediu a deformação do tecido via ultrassonografia para estimar a elasticidade. Desde então, a técnica vem sendo aprimorada e outras diferentes técnicas também foram desenvolvidas com 0 intuito de medir a rigidez dos tecidos.

Atualmente existem duas técnicas de elastografia, dependendo da forma de emissão de ondas: a elastografia por tensão (strain elastography) e a elastografia por ondas de cisalhamento (Shear Wave Elastography - SWE). A mensuração também varia, sendo de forma qualitativa na primeira e quantitativa na segunda ${ }^{32,33}$. 


\subsubsection{Técnica}

\subsubsection{Elastografia por Tensão (Strain Elastography)}

Essa técnica, aperfeiçoada do experimento de Ophir, baseia-se em quantificar a dificuldade de deformação de um tecido relativo à pressão utilizada, através do modelo físico $\mathrm{E}$ de Young ${ }^{(34)}$. Nessa técnica, a pressão mecânica pode ser aplicada pela mão do examinador, conforme figura 6. Uma pressão é aplicada ao transdutor que é transmitido ao tecido no mesmo sentido da compressão, e então o seu deslocamento e sua deformação é medida em duas dimensões conforme figura abaixo, traduzido em escala de cores semitransparente chamado de elastografia. Geralmente tecidos rígidos ou com menor elasticidade são representados na cor azul e tecidos com alta elasticidade (tecidos moles), são representados na cor vermelha. A compressão manual funciona bem para estudo de órgãos superficiais, como mama e tireoide, porém apresenta limitações para estudo de órgãos mais profundos como fígado.

\section{Após compressão estática}

Antes

a

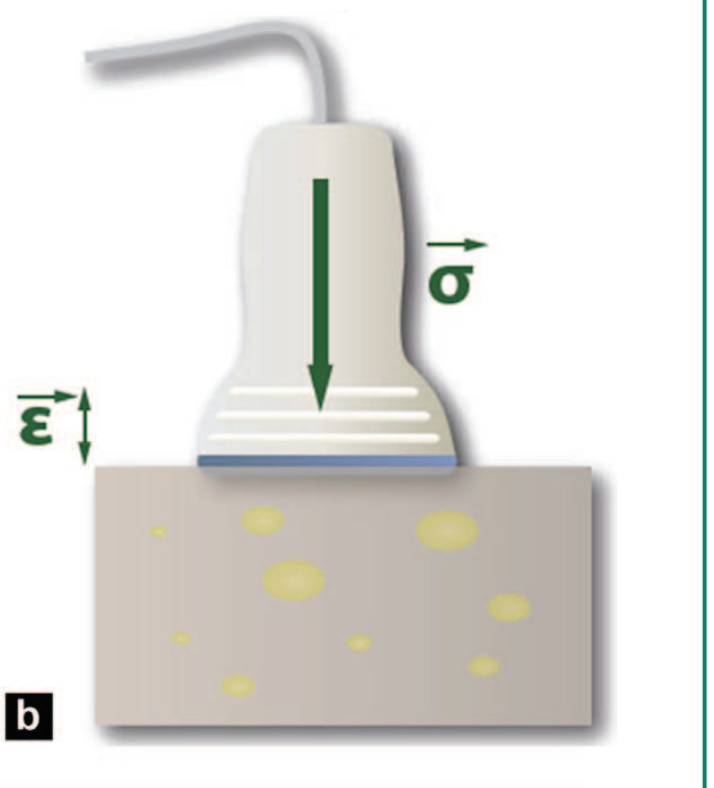

Figura 6 - Elastografia por Tensão. (Adaptado de Gennisson,J.L. ${ }^{35}$ ) 
Esta técnica é utilizada atualmente em algumas indicações clínicas dentre elas, para diagnóstico diferencial de nódulos benignos e malignos de mama $^{36}$ e de tireóide ${ }^{37}$. Como ela só avalia tecidos que são tocados pelo transdutor e a força do examinador não é calculada, suas principais limitações são seu uso para tecidos profundos, sua reprodutibilidade e sua tradução quantitativa.

\subsubsection{2- Elastografia por Tensão com utilização de ARFI}

A técnica da elastografia por tensão também pode utilizar um foco de excitação de impulso de força gerado automaticamente no transdutor, chamado de ARFI (Acoustic Radiation Force Impulse - impulso de força de radiação acústica), que utiliza pulsos acústicos de alta intensidade e curta duração na direção normal, ou seja, perpendicular à superfície. O deslocamento do tecido é medido pela região de interesse de forma qualitativa, semelhante ao método de elastografia por compressão manual, por elastograma, mantendo as limitações supracitadas.

\subsubsection{Elastografia por ondas de Cisalhamento (SWE)}

Nessa técnica, analisa-se a velocidade de propagação de ondas dentro de um tecido. A tensão que gera as ondas de cisalhamento (shearwaves SWE) pode ser aplicada por um vibrador mecânico ou por um transdutor com excitação de ARFI (Quadro 1). Como as ondas são derivadas do transdutor, elas podem ter sua tensão calculada e, portanto, o resultado se dará de maneira quantitativa. 


\subsubsection{Elastrografia por ondas de cisalhamento transitória}

Foi o primeiro aparelho de elastografia por ondas cisalhamento disponível comercialmente (FibroScan TME chosens, Paris, France). É a técnica mais utilizada e validada para estudo de fibrose hepática. A tensão é aplicada por um transdutor de ultrassom que contem um vibrador mecânico, porém não gera imagens ultrassonográficas habituais em modo B. O local a ser estudado e a mensuração da velocidade é realizado através das imagens em modo $A$.

\subsubsection{Elastrografia por ondas de cisalhamento por ARFI}

Em vez de um vibrador mecânico, o ARFI usa pulsos acústicos de alta intensidade e curta duração. Quando a tensão é aplicada por ARFI por ondas de cisalhamento (shear wave imaging) na imagem em um ponto focal, é denominada de elastografia por ondas de cisalhamento focal - pSWE; quando for aplicada em uma área maior, é denominada de elastografia por ondas de cisalhamento em 2D (SWE 2D). A vantagem dessa técnica em relação à elastografia transitória é a possibilidade de visualização do local a ser estudada, evitando vasos e ductos biliares, estruturas que influenciam no resultado final da medida, bem como menor influência de fatores extra-hepáticas, como ascite e obesidade, que também podem alterar a medida, uma vez que as ondas são geradas focalmente na região intra-hepática. É possível escolher o local de um órgão a ser analisado, colocando-se um marcador chamado região de interesse (Region of Interest - ROI) e medir a velocidade de propagação destas ondas neste local. Com esta técnica, portanto, temos a possibilidade de realizar a elastografia de órgãos mais profundos, quantificar a propagação da onda em velocidade $(\mathrm{m} / \mathrm{s})$ e calcular sua equivalência em força (kPA), podendo haver reprodutibilidade. A elastografia por SW em 2D é a técnica mais recente 
e apresenta vantagem em relação à SWE, pois é possível obter uma área maior de analise em tempo real, com maior rapidez na aquisição dos dados.

Quadro 1 - Tipos de elastografia. (Adaptado de Tsukoshi, $S^{38}$ )

\begin{tabular}{|c|c|c|}
\hline $\begin{array}{l}\text { Método de Método } \\
\text { excitação }\end{array}$ & Onda de Tensão & Onda de Cisalhamento \\
\hline Compressão manual & $\begin{array}{l}\text { Imagem de } \\
\text { Elastografia por } \\
\text { tensão }\end{array}$ & \\
\hline $\begin{array}{l}\text { Impulso de força de } \\
\text { radiação acústica }\end{array}$ & Imagem por ARFI & $\begin{array}{l}\text { Velocidade da onda } \\
\text { (m/s) } \\
\text { Modulo de Young } \\
(\mathrm{kPa})\end{array}$ \\
\hline $\begin{array}{l}\text { Vibração mecânica } \\
\text { externa }\end{array}$ & & Módulo de Young \\
\hline
\end{tabular}

\subsubsection{Aplicações clínicas}

De acordo com a rigidez do tecido, podemos obter diferentes ondas de cisalhamento. À medida que o tecido se torna mais rígido, a onda de cisalhamento se propaga mais rápido. Com a utilização de regiões de interesse (ROls) no tecido alvo, podemos obter as medidas das ondas de cisalhamento de forma simples durante o exame de ultrassonografia, em tempo real e sem exposição a qualquer radiação ou necessidade de sedação em crianças. As aplicações clinicas mais comuns são para estudo do parênquima hepático (graduação de fibrose em pacientes com hepatopatia), baço (hipertensão portal), pâncreas, rins (nefropatias), próstata, mama e tireoide (nódulos), porém 
estudos na área de musculosquelético, cerebral e demais órgãos também tem sido descritos ${ }^{39,40}$.

\subsubsection{Limitações}

Apesar das vantagens de não ser invasivo e não utilizar a radiação ionizante, uma das limitações para a aplicação desta técnica na prática clínica é a falta de padronização das medidas ${ }^{(35)}$. As ondas de cisalhamento diferem de acordo com o equipamento e o transdutor utilizados, do fornecedor, da posição do paciente, o tempo de jejum em estudos abdominais, o número de medições, a profundidade de aquisição e os valores representativos como mediana ou valores médios. Esforços para padronizar medidas entre diferentes técnicas de elastografias têm sido realizados. 
JUSTIFICATIVA

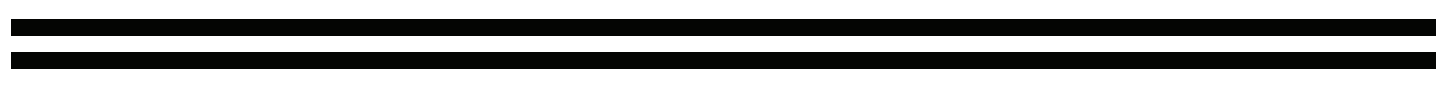




\section{JUSTIFICATIVA}

A avaliação funcional do timo é de suma importância no diagnóstico de imunodeficiências primárias e de agressões exógenas ao timo (infecções, medicamentos, outras). Os métodos disponíveis para sua avaliação são onerosos, apresentam riscos ao paciente ou necessitam de uma estrutura hospitalar terciária. Neste sentido, a utilização da elastografia para avaliação da elasticidade do timo em lactentes e crianças pode representar uma ferramenta útil para avaliação funcional do timo, de fácil acesso, inócua ao paciente e principalmente, sem dor, qualidade fundamental na avaliação do paciente pediátrico. Não há estudo abordando estes aspectos na literatura até a presente data.

A mensuração dos TRECs representa um método consagrado para avaliação da função tímica usando um marcador em sangue periférico, mas ainda pouco disponível para uso clínico, exceto na triagem neonatal, na avaliação de transplante de medula óssea e no controle da reconstituição imunológica após uso de antirretroviral de pacientes com AIDS (síndrome da imunodeficiência adquirida pelo vírus HIV) ${ }^{30}$.

Um melhor conhecimento destes métodos e da possibilidade de associálos contribuiria para uma melhora na avaliação da função tímica na prática clínica. 


\section{HIPÓTESES}

- A elastografia é um método passível de ser utilizado para avaliar função tímica em crianças de baixa idade;

- Existe uma correlação positiva entre dureza do timo avaliadas pela elastografia e sua função avaliada pelos níveis de TRECs em sangue periférico. 


\section{OBJETIVOS}

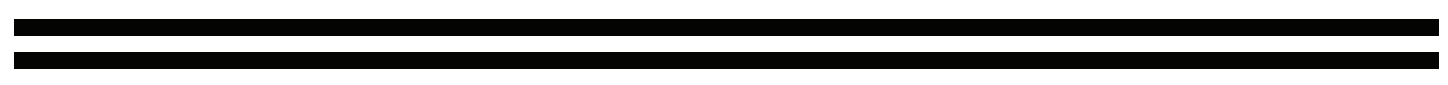




\section{OBJETIVOS}

- Implantar a técnica de elastografia para avaliação de dimensões e dureza do timo em crianças de baixa idade;

- Estabelecer valores de referência de TRECs em crianças de baixa idade, bem nutridas, sem doenças sistêmicas conhecidas agudas ou crônicas identificadas;

- Comparar os valores de TRECs das crianças de baixa idade com o banco de dados do LIM-36 de crianças e adolescentes hígidos entre 10-20 anos;

- Correlacionar dimensões e dureza tímica avaliada à elastografia e níveis de TRECs em sangue periférico. 
ASPECTOS ÉTICOS 


\section{ASPECTOS ÉTICOS}

Os pesquisadores conversaram com os responsáveis pelos participantes do estudo e apenas após esclarecimento de questionamentos sobre a pesquisa e concordância com a assinatura do termo de consentimento livre e esclarecido, os lactentes e crianças foram incluídos na pesquisa.

O protocolo de estudo foi aprovado pelo Comitê de Ética em Pesquisa do Departamento de Pediatria da FMUSP e encaminhado à CAPPesq, onde também foi aprovado sob número: 335.543 (Anexo B). 
METODOLOGIA

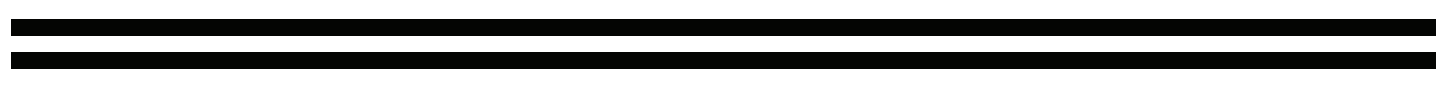




\section{METODOLOGIA}

Os participantes do estudo foram recrutados próximos à área de coleta de exames e também do ambulatório de Cirurgia Pediátrica do Instituto da Criança - HCFMUSP. Foram questionados e avaliados segundo critérios abaixo descritos. Aqueles sujeitos que preenchiam os critérios de inclusão e não apresentavam qualquer critério de exclusão foram abordados pelo pesquisador deste trabalho, sendo explicado o motivo da pesquisa, os riscos e benefícios e dúvidas foram esclarecidas neste momento. Os responsáveis que aceitaram participar, leram e assinaram o termo de consentimento livre e esclarecido. Em seguida, seu filho(a) seguiu para coleta de exames de sangue, solicitados por motivos alheios a esta pesquisa em que $0,3 \mathrm{ml}$ foram destinados ao estudos dos TRECs. Em seguida, ou em outro momento propício, seguiram para realização da elastografia no serviço de radiologia do ICr- HCFMUSP. Quando da aquisição de todos os TRECs de crianças abaixo de 5 anos, comparamos com crianças e adolescentes de 10 a 20 anos do banco de dados do LIM-36 (Laboratório de Investigação Médica) do Instituto da Criança - HCFMUSP.

\section{Critérios de Inclusão:}

- $\quad$ Idade entre 0 a 5 anos;

- $\quad$ Ambos os gêneros.

\section{Critério de exclusão:}

- História conhecida de imunodeficiência ou de outra doença crônica;

- $\quad$ Uso atual ou no último mês de corticosteroides;

- Doença sistêmica ou infecção atual aguda ou crônica. 


\subsection{Elastografia}

Realizados no Serviço de Radiologia do ICr- HCFMUSP, os exames de ultrassonografia e elastografia foram feitos com equipamento Epiq 7G (Philips Healthcare - Best, the Netherlands - software versão1.8), utilizando-se 0 transdutor convexo multifrequêncial C5-1. A elastografia disponível no equipamento é por ondas de cisalhamento com possibilidade de análise de uma área maior (SWE 2D), a elastoQ, que permite uma área de interesse (box) amplo e obtenção de mais de uma medida por imagem.

O aparelho então foi calibrado para escala padrão de 0-30 kPa ou 0-3.2 $\mathrm{m} / \mathrm{s}$.

Os exames foram realizados por uma única radiologista pediátrica com 25 anos de experiencia, com ênfase em ultrassonografia.

Os pacientes foram posicionados em decúbito dorsal, sem jejum, com leve extensão do pescoço. As janelas acústicas utilizadas foram supraclavicular e paraesternal.

As medidas do timo, tanto das dimensões como da elastografia, foram obtidas no timo localizado na região anterior ao tronco venoso braquiocefálico esquerdo, geralmente na linha média, onde há a melhor visualização do mesmo.

Foram obtidas no mínimo cinco medidas de elastografia, posicionandose a região de interesse no centro do timo, utilizando-se o "cine loop". Foram obtidos no máximo duas medidas para cada imagem de cine loop, com IQR (Interquartil Range) de até 30\%. O IQR abaixo de 30\% é um parâmetro de confiabilidade das medidas obtidas (figura abaixo). 


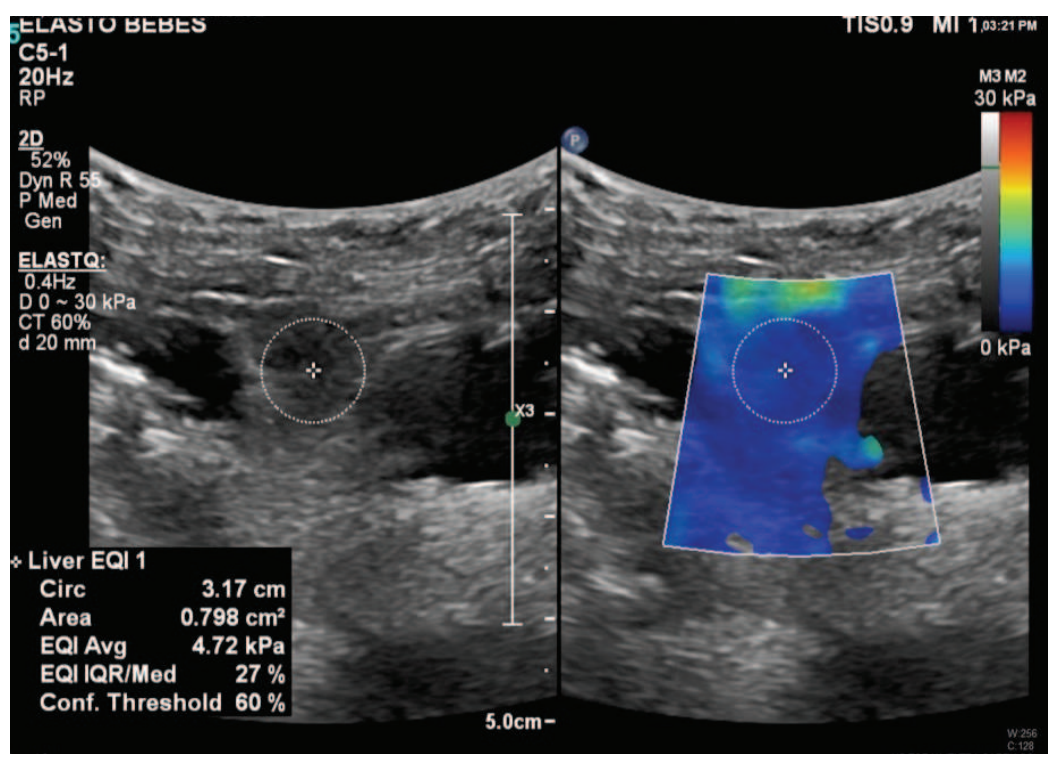

Figura 7 - Imagem de elastografia de timo mostrando tela com IQR de $27 \%$, ou seja, grau de confiabilidade que valida o exame.

O volume do timo foi calculado utilizando-se a formula elipsoide, multiplicando-se as medidas do timo nos eixos longitudinal, anteroposteiror e laterolateral $\times 0,52$, tendo como referencia o tronco venoso traqueocefálico esquerdo. 


\subsection{Quantificação do número de cópias de TREC em sangue total}

Os exames de TREC foram realizados no LIM 36 do Instituto da Criança HCFMUSP conforme descrição abaixo.

\section{A. Extração e Quantificação do DNA}

As amostras de sangue total coletadas em tubo contendo anticoagulante EDTA foram utilizadas para extração de DNA, utilizando o kit de extração QIAamp DNA Blood (Qiagen, Valencia, CA, USA) de acordo com as instruções do fabricante. Após a extração, uma alíquota de $2 \mu \mathrm{L}$ da amostra de DNA foi quantificada no espectrofotômetro NanoVue Plus (GE Healthcare, Buckinghamshire, UK). Através do cálculo das razões 260/280 e 260/230 foi possível verificar a pureza do material em análise. Utilizamos o valor de referência 1.8 para a pureza do DNA.

O material quantificado foi mantido à temperatura de $-20^{\circ} \mathrm{C}$ até o momento do uso.

B. Quantificação dos círculos de excisão do receptor de célula T

O ensaio de TRECs inclui a extração do DNA do sangue do paciente e/ou amostras controle, em seguida este material é submetido ao processo de qPCR em tempo real. O número de cópias de TRECs é calculado em relação a uma curva padrão gerada a partir da diluição seriada de plasmídeos, os quais têm um número conhecido de TRECs, através de uma quantificação absoluta. 


\section{Transformação bacteriana e extração do DNA plasmidial}

Os segmentos gênicos de TRECs e $\beta$-actina (gene utilizado como controle endógeno da reação) foram clonados em plasmídeos segundo o protocolo descrito por Douek DC et al. ${ }^{41}$. Uma alíquota de cada plasmídeo foi gentilmente cedida pela Dra Leuridan C. Torres, do laboratório de Pesquisa Translacional do Instituto de Medicina Integral Prof. Fernando Figueira - IMIP, em Pernambuco.

O próximo passo foi transformar as bactérias Escherichia coli $D H 10 B^{T M}$, proveniente no kit OneShot ${ }^{\circledR}$ competentcells (Invitrogen), com os vetores contendo os insertos. Em um tubo contendo as bactérias E. coli competentes, foi adicionado $1 \mu \mathrm{l}$ do vetor e em seguida incubadas em gelo por 30 minutos. Após este período, a mistura (vetor/bactéria) foi submetida à transformação por choque térmico a $42^{\circ} \mathrm{C}$ por 30 segundos. Em seguida, foram adicionados 250 $\mu \mathrm{l}$ de meio de cultura $\mathrm{SOC}$ à mistura, seguido da incubação a $37^{\circ} \mathrm{C}$ por 1 hora, em agitação a 250 rpm.

Após este período, as bactérias foram semeadas em placas de Petri contendo $35 \mathrm{~mL}$ de meio de cultura LB ágar com antibiótico ampicilina (100 $\mu \mathrm{g} / \mathrm{mL}$ ) previamente preparadas. Em seguida, as placas foram incubadas a $37^{\circ} \mathrm{C}$ por 24 horas e o antibiótico possibilitou a seleção das colônias transformadas.

As colônias no meio sólido foram selecionadas e cultivadas em $5 \mathrm{~mL}$ de meio de cultura LB líquido com ampicilina sob agitação constante a $37^{\circ} \mathrm{C}$ por 12-16 horas.

D. Purificação do DNA plasmidial de bactérias (E. coli) contendo TREC e $\beta$-actina

A extração do DNA plasmidial (TREC e $\beta$-actina) das bactérias transformadas foi feita com 0 kit de purificação PureLink® Quick 
PlasmidMiniprep (Invitrogen), de acordo com as instruções do fabricante. Após a purificação do DNA, o material foi submetido à eletroforese em gel de agarose $1 \%$ e quantificado no espectrofotômetro NanoVue Plus (GE Healthcare, Buckinghamshire, UK).

\section{E. Detecção e quantificação das partículas de TRECs e $\beta$ - actina}

Para a preparação da curva padrão após a quantificação do DNA plasmidial, foi utilizado um cálculo que levou em consideração a massa molecular do plasmídeo mais a massa molecular do inserto, tanto dos TRECs quanto da $\beta$ - actina.

A partir da massa de cada molécula e da quantificação do DNA plasmidial, foi possível estabelecer o número de moléculas de DNA plasmidial $/ \mu \mathrm{L}$. Este DNA foi diluído em água ultrapura para a concentração final de 1 x109 moléculas de DNA plasmidial/ $\mu$ L. A partir desta concentração, foram feitas diluições seriadas com fator 1:10, tanto para o DNA plasmidial de TREC quanto da $\beta$ - actina, constituindo assim os pontos da curva padrão (1 x106 - 1 x 102 moléculas $/ \mu L)$. A quantificação do número de cópias de TRECs nas amostras controles e dos pacientes foram determinadas pelo método de reação em cadeia de polimerase quantitativo em tempo real (qPCR), utilizando o equipamento Step One Plus TMReal-Time PCR System (Applied Biosystems, Foster City, CA, USA).

\section{F. Quantificação absoluta de TRECs por qPCR}

As reações de quantificação absoluta do fragmento de TREC e do controle endógeno foram realizadas utilizando-se um volume final de $25 \mu \mathrm{L}$, as quais foram adicionadas $300 \mathrm{ng}$ totais de DNA genômico extraído do sangue 
total dos pacientes. Para isto utilizamos o reagente TaqMan® Universal PCR master mix (Applied Biosystems, Foster City, CA, USA). As concentrações dos oligonucleotídeos iniciadores e das sondas foram previamente padronizados, sendo utilizados a concentração $20 \mu \mathrm{M}$ para os oligos iniciadores forward e reverse para ambos os genes avaliados, e a concentração de $15 \mu \mathrm{M}$ para as sondas de TREC e $\beta$ - actina. As sequências dos oligonucleotídeos e das sondas são mostradas na tabela abaixo:

Quadro 2 - Sequencias de Referências dos oligonucletídeos e sondas

\begin{tabular}{ll}
\hline Nome & Sequencia \\
\hline TREC Forward Primer & 5'- CAC ATC CCT TTC AAC CAT GCT -3' \\
TREC Reverse Primer & 5'- GCC AGC TGC AGG GTT TAG G - 3' \\
$\beta$-actin Forward Primer & 5'-ATT TCC CTC TCA GGC ATG GA-3' \\
$\beta$-actin Reverse Primer & 5'-CGT CAC ACT TCA TGA TGG AGT TG-3' \\
TREC Probe & 6-FAM-ACA CCT CTG GTT TTT GTA AAG GTG CCC \\
& ACT- \\
$\beta$-actinProbe & 3'-TAMRA \\
\hline
\end{tabular}

As amostras e a curva padrão de TRECs e $\beta$-actina foram feitas em triplicata em placas opticas de 96 poços. A ciclagem utilizada nas reações foi $50^{\circ} \mathrm{C}$ por 2 minutos, $95^{\circ} \mathrm{C}$ por 10 minutos, seguidos de 40 ciclos de $95^{\circ} \mathrm{C}$ por 30 segundos e $60^{\circ} \mathrm{C}$ por 1 minuto. Os dados obtidos foram armazenados em planilha no Programa Excel para posterior análise estatística.

\section{G. Curva Padrão de TRECs e $\beta$-actina}

Para a padronização da curva padrão de TREC e de $\beta$-actina, foram realizadas diluições seriadas com fator 1:10, a partir da concentração inicial de 1X109 cópias de moléculas de DNA/ $\mu \mathrm{L}$ para ambos os plasmídeos como citado anteriormente. Foram selecionados cinco pontos, os quais as concentrações variaram de $1 \times 10^{2}$ a $1 \times 10^{6}$ moléculas de DNA. A quantidade de cópias de TREC obtida de uma determinada amostra, foi apresentada como o número de 
cópias de TREC/ $\mu \mathrm{L}$ de DNA genômico. A quantidade de DNA utilizada de cada amostra foi de $5 \mu \mathrm{L}$ por reação. A $\beta$-actina, por ser um gene constitutivamente expresso em todos os tipos celulares, foi utilizada como controle endógeno, para eliminar as diferenças na amplificação causadas por possíveis diferenças na quantificação de DNA.

Como visto nas figuras 1 e 2, durante os ciclos iniciais da reação, não há acúmulo de produtos de amplificação e os valores de $\Delta R \mathrm{R}$ permanecem na linha de base. $\Delta R n$, indica a diferença na intensidade de fluorescência do fluoróforo das sondas usadas (FAM e VIC) e do controle interno passivo utilizado nas reações (ROX). Na fase logarítmica da reação ocorre acúmulo dos produtos de amplificação e o valor de $\Delta R n$ ultrapassa a linha de base (threshold). O threshold deve ser posicionado na região de amplificação exponencial das curvas de amplificação, em um ponto acima do ruído basal e abaixo da fase linear da amplificação. $O$ ciclo em que a amostra excede a fluorescência basal (Ct ou thresholdcycle) indica a quantidade de DNA alvo presente na amostra. Para TREC o threshold estabelecido foi de 0,050832, e para a $\beta$-actina foi de 0,003563.A eficiência e o slope (distância entre os pontos) da curva também foram padronizados, sendo utilizado as curvas que apresentaram eficiência de 96 a 99\% e com o slope entre -3,651 a -3,199. A partir dos valores padronizados, a análise dos resultados foi realizada pelo software StepOnePlusTM (Applied Biosystems, Foster City, CA, USA), que em função do posicionamento do threshold escolhido faz os cálculos da quantidade de DNA alvo presente na amostra. 

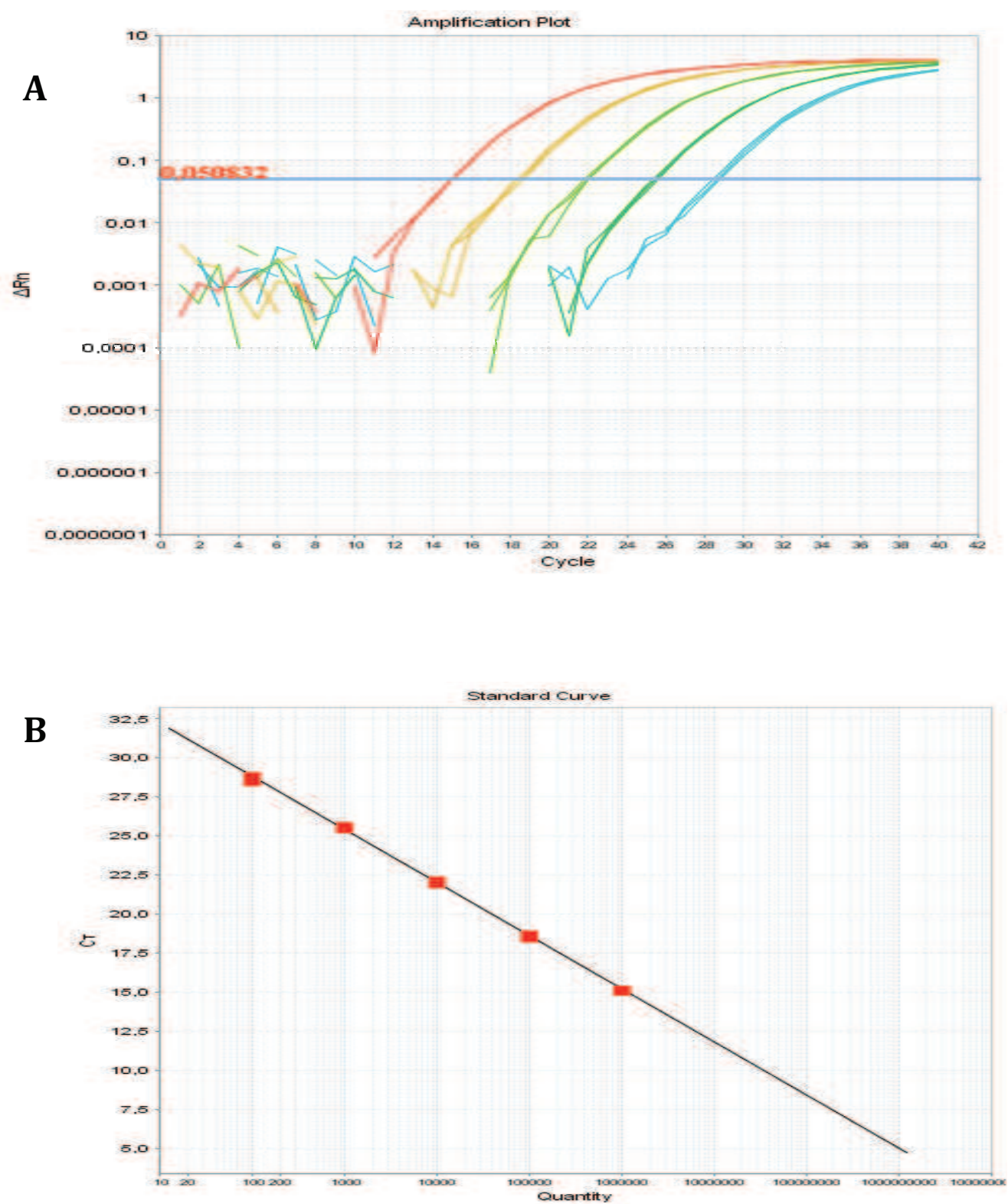

Figura 8. Curvas de amplificação das diferentes diluições de TREC (I).

A figura A mostra as curvas de amplificação das diferentes diluições de TREC, $1 \times 10^{6}$ a $1 \times 10^{2}$ moléculas. A linha azul indica o threshold de 0,050832 estabelecido para a análise. No gráfico $B$, observa-se a curva padrão, cujo slope foi de $-3,4455, R^{2}=0,99$, eficiência=97,1\% 


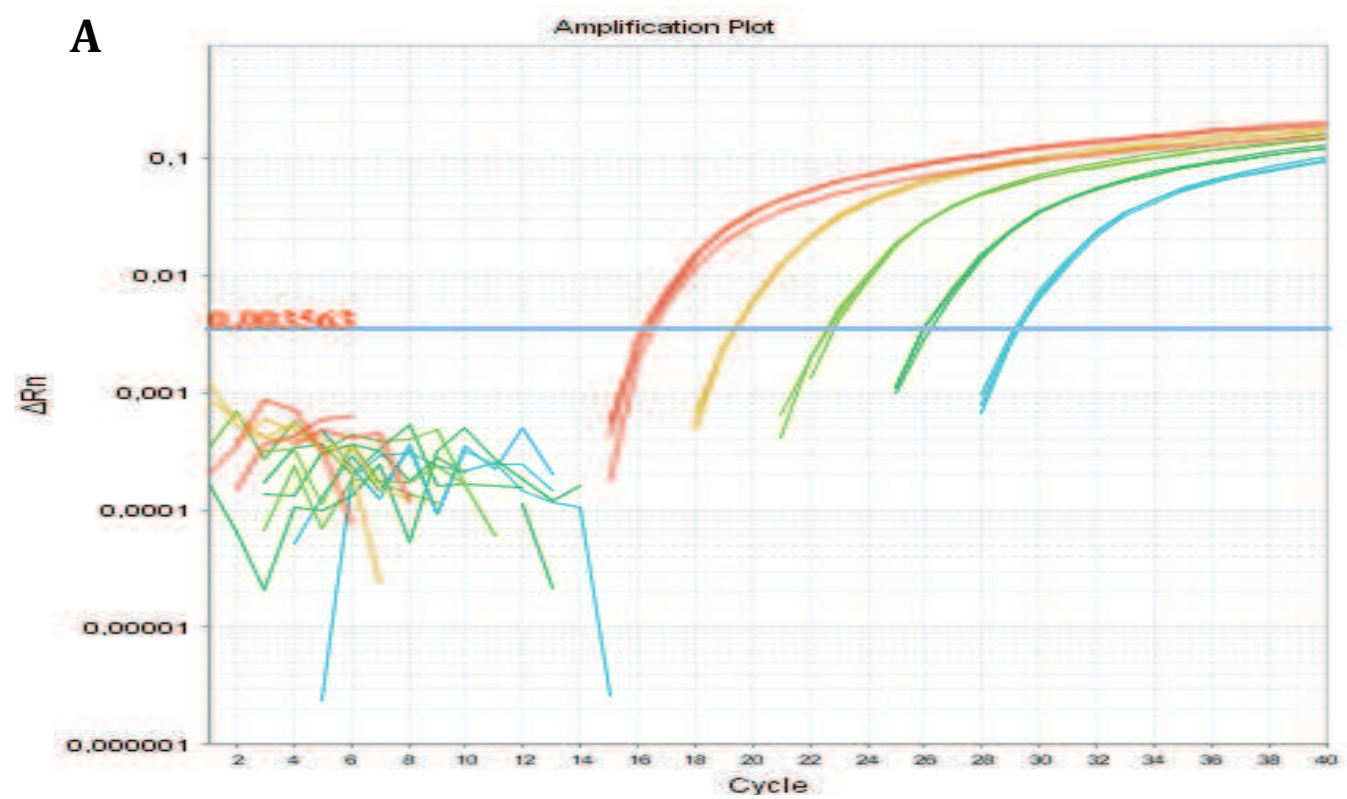

B

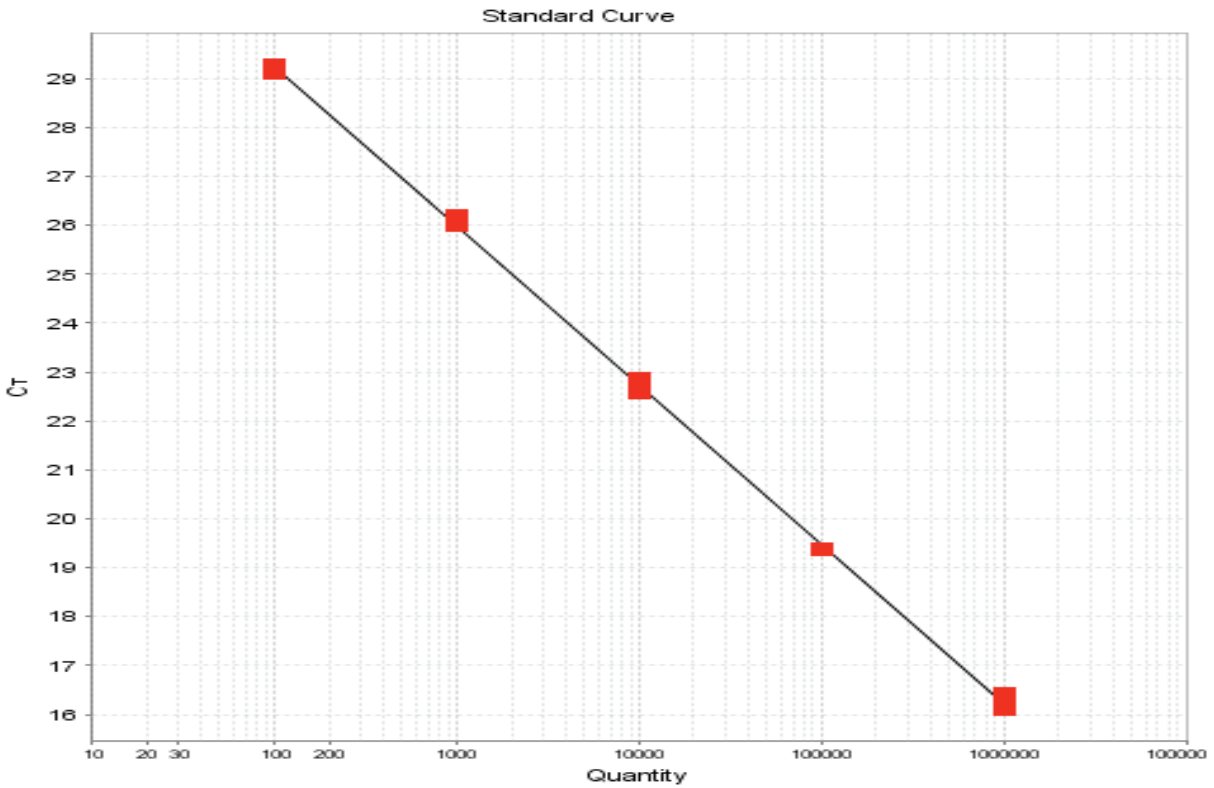

Figura 9. Curvas de amplificação das diferentes diluições de TREC (II). A figura A mostra as curvas de amplificação das diferentes diluições de TREC, $1 \times 10^{6}$ a $1 \times 10^{2}$ moléculas. A linha azul indica o threshold de 0,003563 estabelecido para a análise. No gráfico $B$, observa-se a curva padrão, cujo slope foi de $-3,184, R^{2}=0,99$, eficiência $=98,8 \%$ 
ANÁLISE ESTATÍSTICA 


\section{ANÁLISE ESTATÍSTICA}

A análise estatística foi realizada utilizando-se o programa SPSS para Windows, versão 18 (SPPS Corp., Chicago, USA).

As variáveis categóricas foram apresentadas de modo descritivo em tabelas contendo frequências absolutas ( $n$ ) e relativas $(\%)$.

Realizado teste de normalidade das variáveis utilizando teste de Shapiro-Wilk e as variáveis com distribuição normal foram apresentadas também de modo descritivo em tabelas contendo média e desvio padrão. As variáveis que não apresentavam distribuição normal, foram apresentadas a mediana e intervalo interquartil $(25-75 \%)$.

Para análise de correlação entre elastografia do timo e o número de TRECs foi utilizado o coeficiente de correlação de Spearman.

Os valores de $p<0,05$ foram considerados estatisticamente significantes. 
CUSTEIO

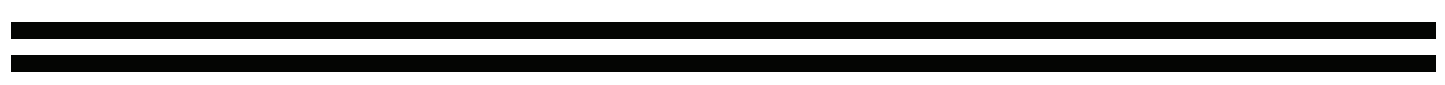




\section{CUSTEIO}

Este trabalho insere-se em um projeto Temático financiado pela FAPESP"Timo humano desenvolvimento e doenças" (\# 2014/50489-9)

Projeto Equipamento multiusuário: 'Elastografia por ultrassom para investigação segura de dimensões e textura de órgãos em crianças'

Processo FAPESP 2015/26791-0 
RESULTADOS

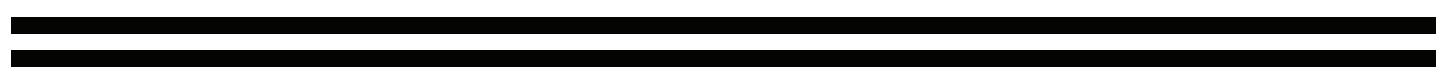




\section{RESULTADOS}

$\mathrm{Na}$ sala de espera do ambulatório de pequenas cirurgias do grupo de Cirurgia Pediátrica do ICr- HCFMUSP foram abordados os pais ou responsáveis de 64 crianças que se encaixavam nos critérios de inclusão e nenhum dos de exclusão do estudo. Neste momento recebiam também a solicitação para realização da elastografia e coleta de sangue para análise do TRECs que seria coletado no momento da indução anestésica para cirurgia (ou junto com os exames pré-operatórios. Destes, 17 não coletaram exame de sangue por dificuldades técnicas. Assim, os dados de 47 crianças foram analisados para TRECs. Destes, 16 não realizaram elastografia e dos que realizaram, 17 estavam inadequadas (IQR $>30 \%$ ), portanto foram analisados 13 elastografias. (Figura 10)

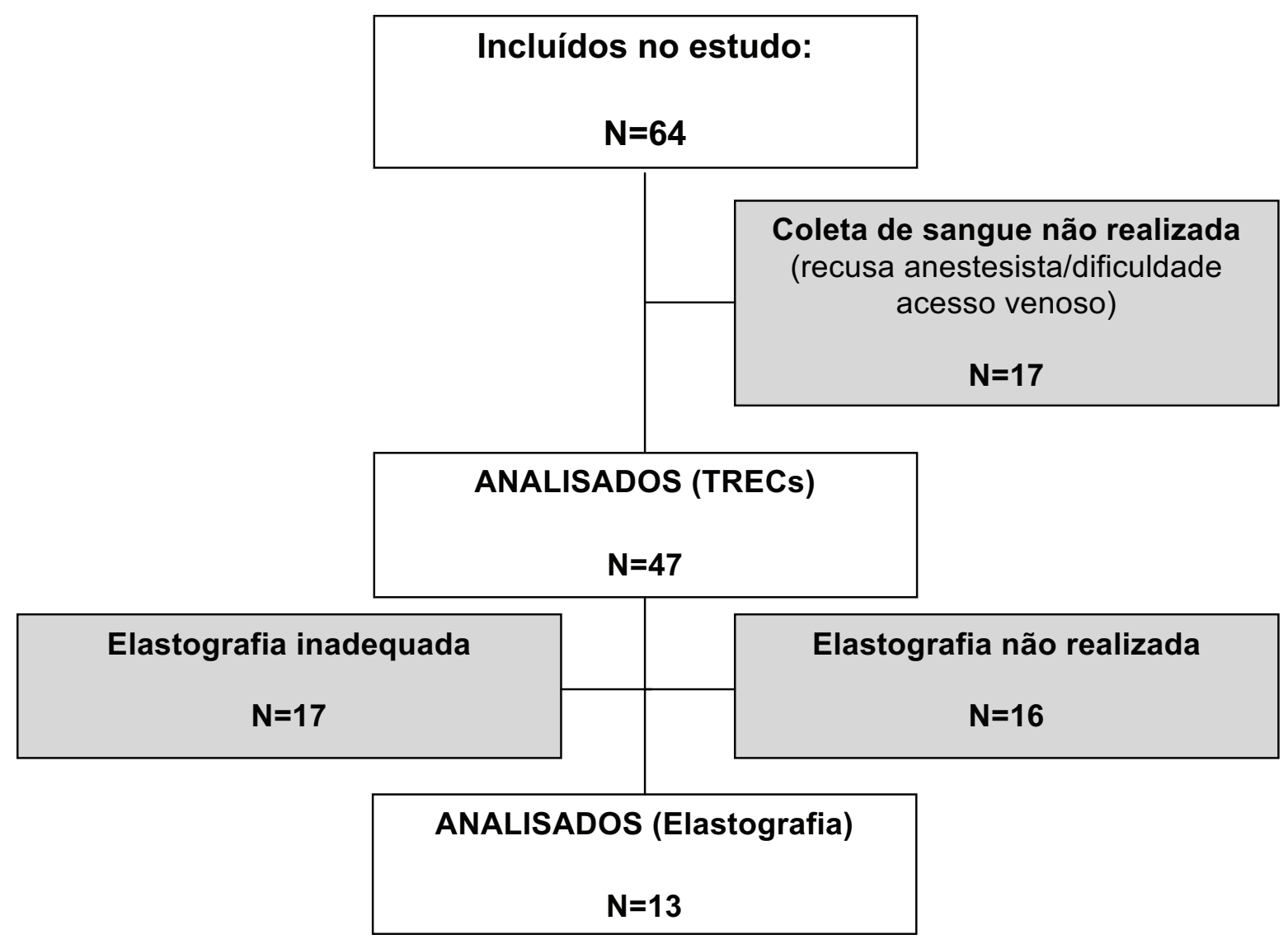

Figura 10 - Fluxograma de inclusão 


\subsection{Análise dos parâmetros elastográficos}

Analisando os dados dos 13 pacientes que realizaram elastografia de forma adequada, verificamos predomínio do gênero masculino, consistindo em $92 \%$ da população estudada. Em razão dos tipos de cirurgia, verificamos que $60 \%$ consistiram em cirurgias urológicas para correção de pequenos defeitos anatômicos. Em relação ao histórico gestacional, 69\% nasceram de termo (Tabela 1).

Tabela 1 - Características demográficas e histórico gestacional (Grupo elastografia)

\begin{tabular}{ll}
\hline Variável & $\mathrm{N}=13$
\end{tabular}

Idade (meses), média \pm DP $33 \pm 14$

\section{Gênero}

$\mathrm{F} / \mathrm{M}, \mathrm{n}(\%)$

$1(8) / 12(92)$

Gestação a termo ( $\geq 38$ semanas); $n$ (\%)

Baixo peso ao nascer $(<2500 \mathrm{~g})$; $\mathrm{n}(\%)$

\section{Tipo de cirurgia}

Urológica (hidrocele, criptoquidia, hipospádia, meatotomia, orquidoplexia), $n(\%)$

Hernioplastia inguinal/umbilical, $\mathrm{n}(\%)$

Ressecção: tela/cisto sebáceo/linfonodo/granuloma

Esvaziamento de fecaloma, $n(\%)$

Fechamento de gastrostomia, $\mathrm{n}(\%)$

Exérese de cisto em tireoglosso, $\mathrm{n}(\%)$ 
Considerando os parâmetros da elastografia verificamos que a mediana e o intervalo interquartil em $\mathrm{kPa}$ foi semelhante entre as faixas etárias 12 a 24 meses, 25 a 36 meses e 37 a 48 meses com tendência de aumento na faixa etária 49 a 60 meses. (Tabela 2)

Tabela 2 - Distribuição dos parâmetros da elastografia (kPa) por faixa etária

\section{Faixa Etária (meses)}

$$
\mathrm{kPa}
$$

mediana [IIQ]

\begin{aligned} \hline 12 a $24(n=5) ;$ mediana [IIQ] & $4,30[3,86-4,49] \\ 25$ a $36(n=4) ;$ mediana [IIQ] & $3,57[3,30-4,47] \\ 37$ a $48(n=2) ;$ mediana [IIQ] & $4,60[3,90-4,60] \\ 49$ a $60(n=2) ;$ mediana [IIQ] & $7,70[3,72-7,70] \\$\hline IIQ - intervalo interquartil & \end{aligned}

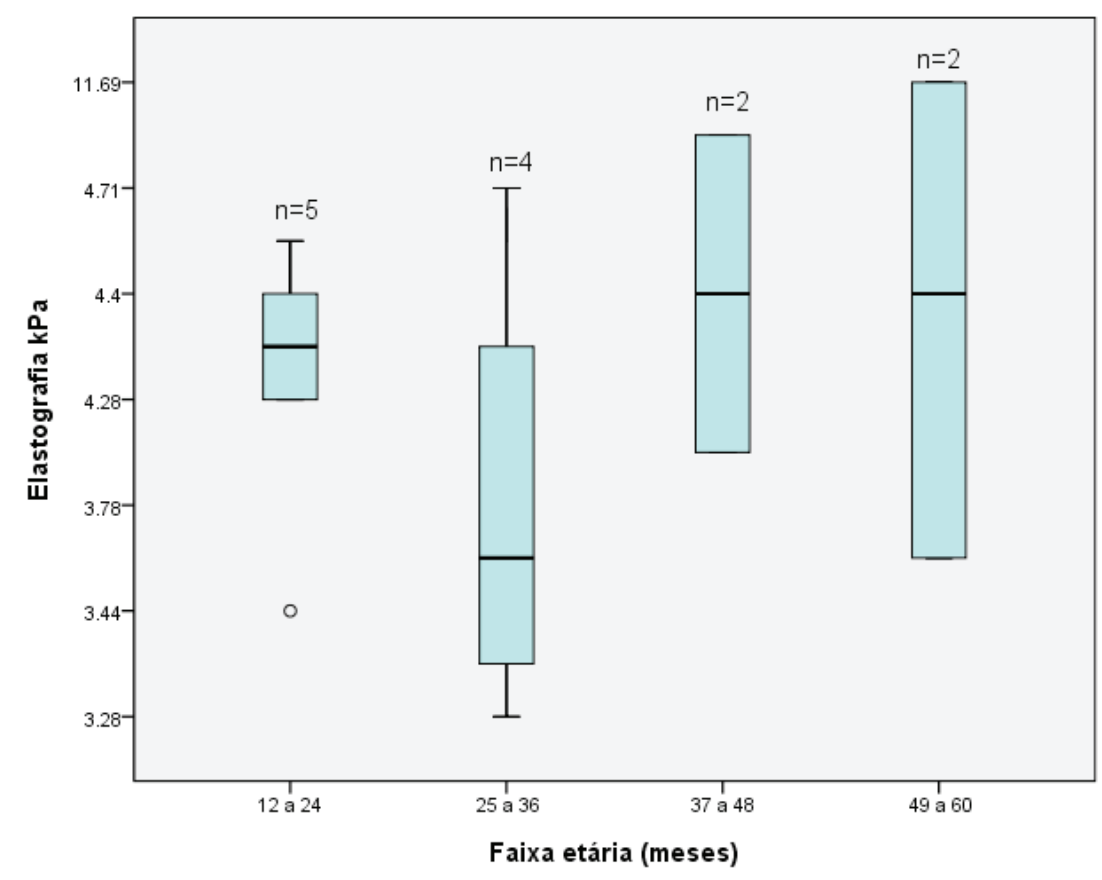

Figura 11 - Distribuição dos parâmetros da elastografia (kPa) por faixa etária (box-plot) 
Considerando os parâmetros da elastografia em $\mathrm{m} / \mathrm{s}$, verificamos que a mediana e intervalo interquartil foram semelhantes entre as faixas etárias 12 a 24 meses, 25 a 36 meses e 37 a 48 meses. (Tabela 3)

Tabela 3 - Distribuição dos parâmetros da elastografia $(\mathrm{m} / \mathrm{s})$ por faixa etária.

\section{Faixa Etária (meses) Elastografia média $(\mathrm{m} / \mathrm{s})$}

$$
\mathrm{n}=13 \quad \text { mediana [IIQ] }
$$

\begin{tabular}{rc}
\hline 12 a $24(\mathrm{n}=5) ;$ mediana [IIQ] & $1,19[1,11-1,21]$ \\
25 a $36(\mathrm{n}=4) ;$ mediana [IIQ] & $1,08[1,04-1,20]$ \\
37 a $48(\mathrm{n}=2) ;$ mediana [IIQ] & $1,22[1,13-1,22]$ \\
49 a $60(\mathrm{n}=2) ;$ mediana [IIQ] & $1,53[1,10-1,53]$ \\
\hline $\mathrm{IIQ}$ - intervalo interquartil &
\end{tabular}

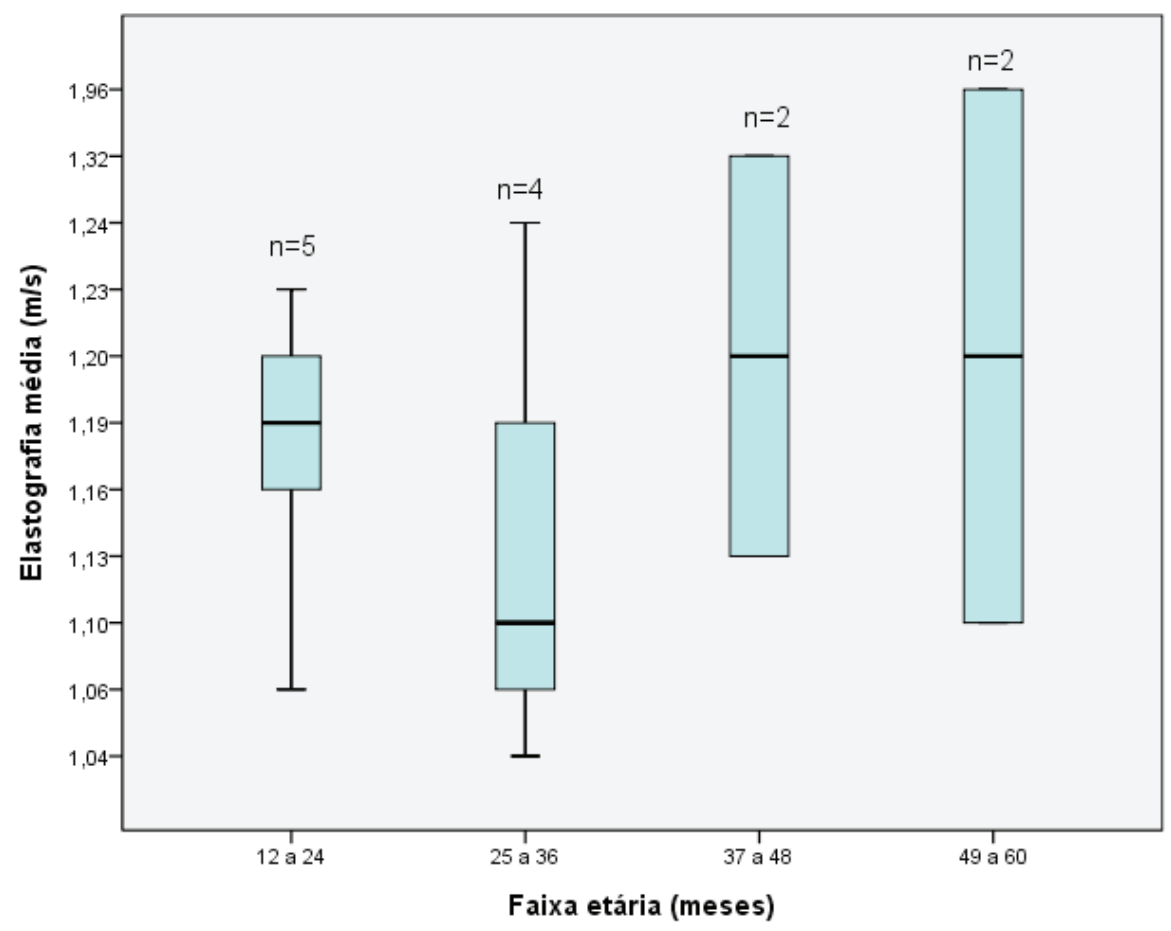

Figura 12 - Distribuição dos parâmetros da elastografia $(\mathrm{m} / \mathrm{s})$ por faixa etária 


\subsection{Análise dos dados de TRECs}

Analisando os dados dos 47 pacientes que coletaram TRECs, verificamos predomínio do gênero masculino, consistindo em $75 \%$ da população estudada em razão dos tipos de cirurgia, sendo que $44 \%$ consistiram em cirurgias urológicas para correção de pequenos defeitos anatômicos. Em relação ao histórico gestacional, 72\% nasceram de termo, conforme Tabela 4.

Tabela 4 - Características demográficas e histórico gestacional (Grupo TRECs)

\begin{tabular}{ll}
\hline Variável & $\mathrm{N}=47$
\end{tabular}

Idade (meses), média \pm DP $36 \pm 16$

\section{Gênero}

$\mathrm{F} / \mathrm{M}, \mathrm{n}(\%)$

$12(25) / 35(75)$

Gestação a termo ( $\geq 38$ semanas); n (\%)

Baixo peso ao nascer (<2500 g); n (\%)

\section{Tipo de cirurgia}

Urológica (hidrocele, criptoquidia, hipospádia, meatotomia, orquidoplexia), $\mathrm{n}(\%)$

Hernioplastia inguinal/umbilical, $\mathrm{n}(\%)$

Ressecção: tela/cisto sebáceo/linfonodo/granuloma

Esvaziamento de fecaloma, $\mathrm{n}(\%)$

Fechamento de gastrostomia, $\mathrm{n}(\%)$

Exérese de cisto em tireoglosso, $\mathrm{n}(\%)$

Outras, $\mathrm{n}(\%)$

Não cirurgia, $n(\%)$

Em relação à distribuição das TRECs e faixa etária, parece existir uma tendência de diminuição de número de TRECs em sangue total por idade 
cronológica, porém sem significância estatística, conforme demonstrado na Tabela 5 e Figura 13.

Tabela 5 - Distribuição da TRECs (cópias/uL) por faixa etária.

\begin{tabular}{cc}
\hline $\begin{array}{c}\text { Faixa Etária (meses) } \\
\mathbf{n}=\mathbf{4 7}\end{array}$ & $\begin{array}{c}\text { TRECs (cópias/uL) } \\
\text { mediana }[I \mathrm{Q}\}\end{array}$ \\
\hline 0 a $12(\mathrm{n}=3) ;$ mediana $[\mathrm{IIQ}]$ & $231,0[201,0-231,0]$ \\
13 a $24(\mathrm{n}=13) ;$ mediana $[\mathrm{IIQ}]$ & $225,0[104,5-292,5]$ \\
25 a $36(\mathrm{n}=7) ;$ mediana $[\mathrm{IIQ}]$ & $118,0[98,0-215,0]$ \\
37 a $48(\mathrm{n}=11) ;$ mediana $[\mathrm{IIQ}]$ & $208,0[81,0-294,0]$ \\
49 a $60(\mathrm{n}=13) ;$ mediana $[\mathrm{IIQ}]$ & $109,0[78,0-134,0]$ \\
\hline
\end{tabular}

IIQ - intervalo interquartil

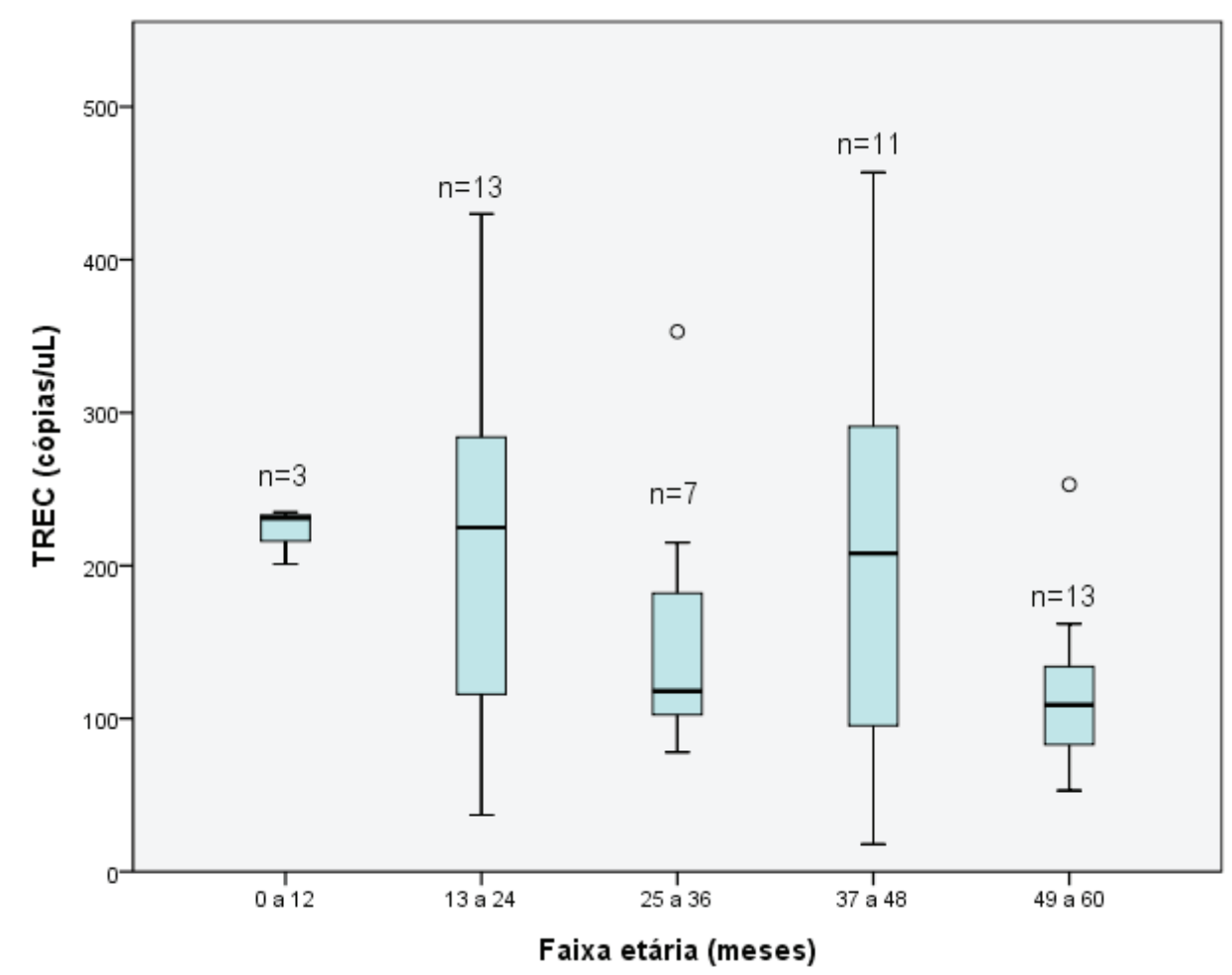

Figura 13 - Distribuição dos números de TRECs (cópias/ $\mu \mathrm{L}$ ) por faixa etária (Box-plot). 


\subsection{Análise comparativa do perfil elastográfico e TRECs}

Quando considerado o perfil elastográfico e TRECs verificamos que a média do volume do timo foi de $12,43 \mathrm{~cm}^{3}$ e o resultado da média de elastografia foi 1,21 $\mathrm{m} / \mathrm{s}$ e/ou 4,67 de $\mathrm{kPa}$. A média de TRECs de 195,6 cópias $/ \mu \mathrm{L}$. (Tabela 6 )

Tabela 6 - Perfil elastográfico e TRECs da população estudada.

Variável $n=13$

USG - volume Timo (cm³); média \pm DP $12,43 \pm 8,33$

Elastografia média $(\mathrm{m} / \mathbf{s})$; média $\pm \mathrm{DP} \quad 1,21 \pm 0,24$

Elastografia $\mathbf{k P a}$; média $\pm \mathrm{DP} \quad 4,67 \pm 2,19$

TRECs (cópias/ML) ; média \pm DP $\quad 195,6 \pm 120,5$ 
A correlação entre volume de timo e número de TRECs em sangue total é mostrada na Figura 14, porém esta correlação não foi verificada.

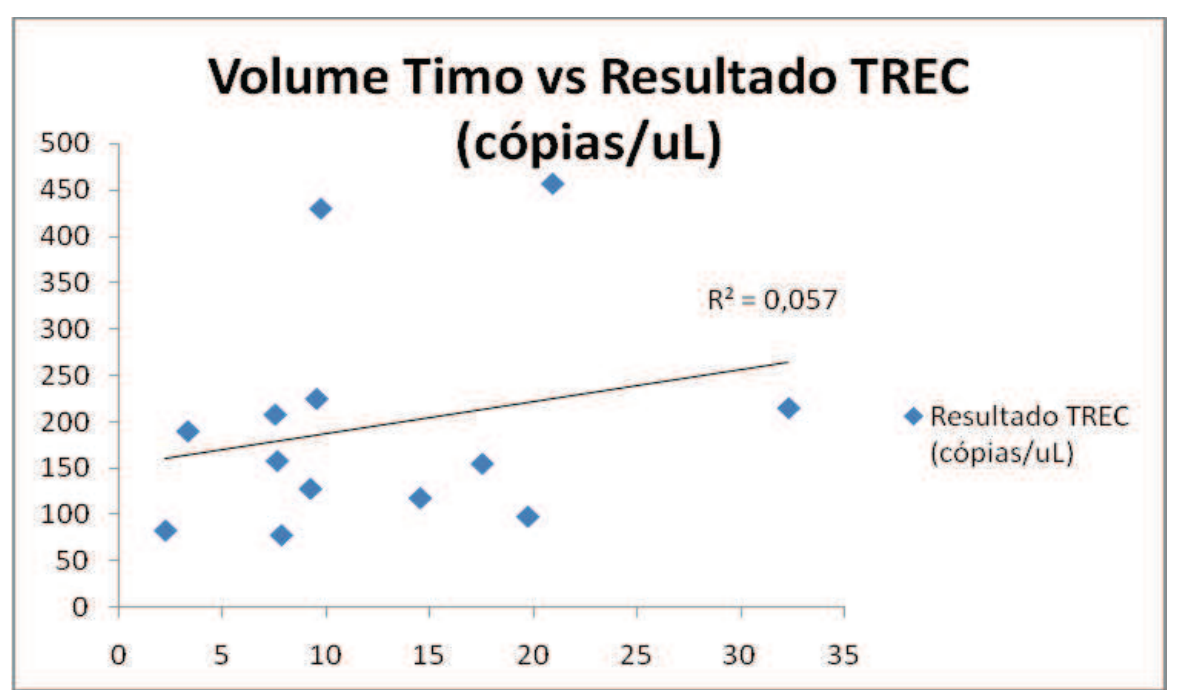

Figura 14 - Correlação entre volume de timo e número de TRECs (sangue total)

O índice de correlação de Spearman entre elastografia em $\mathrm{m} / \mathrm{s}$ e número de TRECs em sangue total é apresentado na Figura 15.

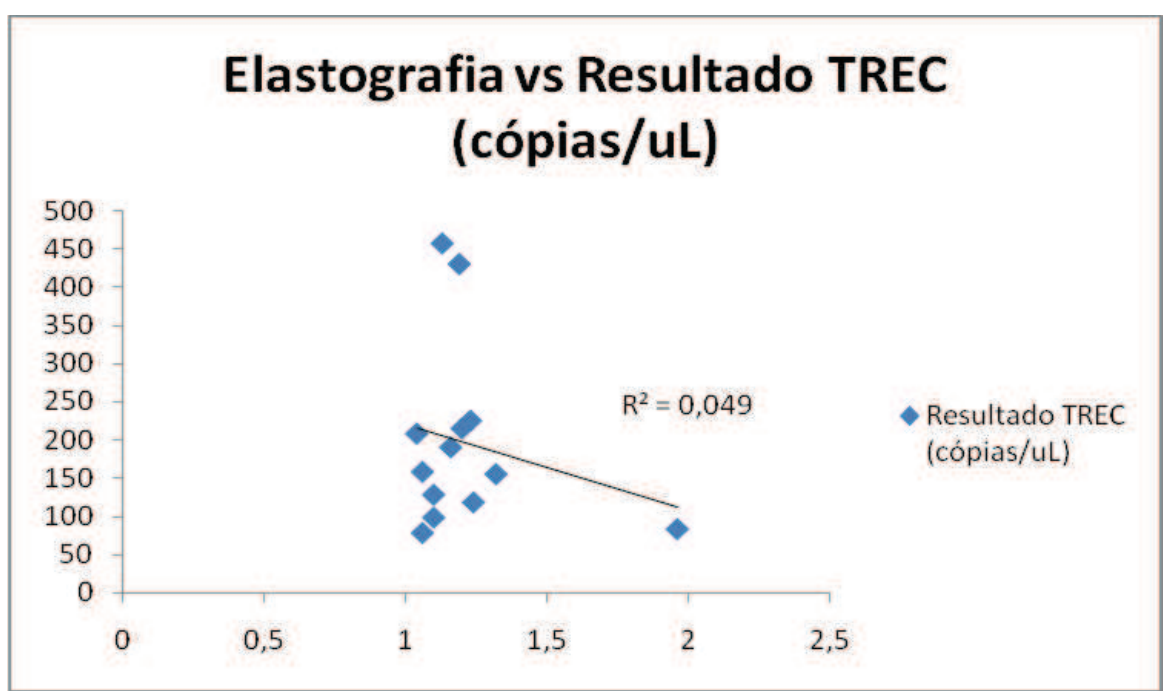

Figura 15 - Correlação de Spearman entre elastografia $(\mathrm{m} / \mathrm{s})$ e número de TRECs (sangue total) 
O índice de correlação de Spearman entre elastografia em kPa e número de TRECs em sangue total é apresentado na Figura 16.

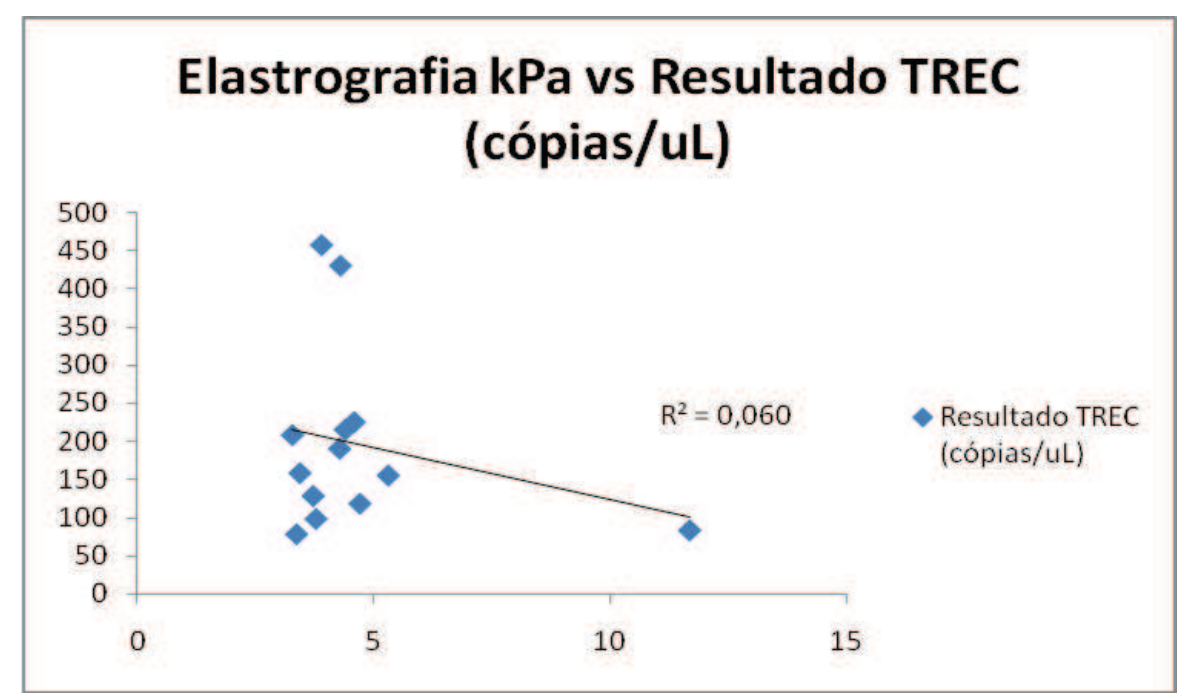

Figura 16 - Correlação de Spearman entre elastografia em kPa e número de TRECs (sangue total)

O índice de correlação de Spearman entre volume do timo e idade é apresentada na Figura 17.

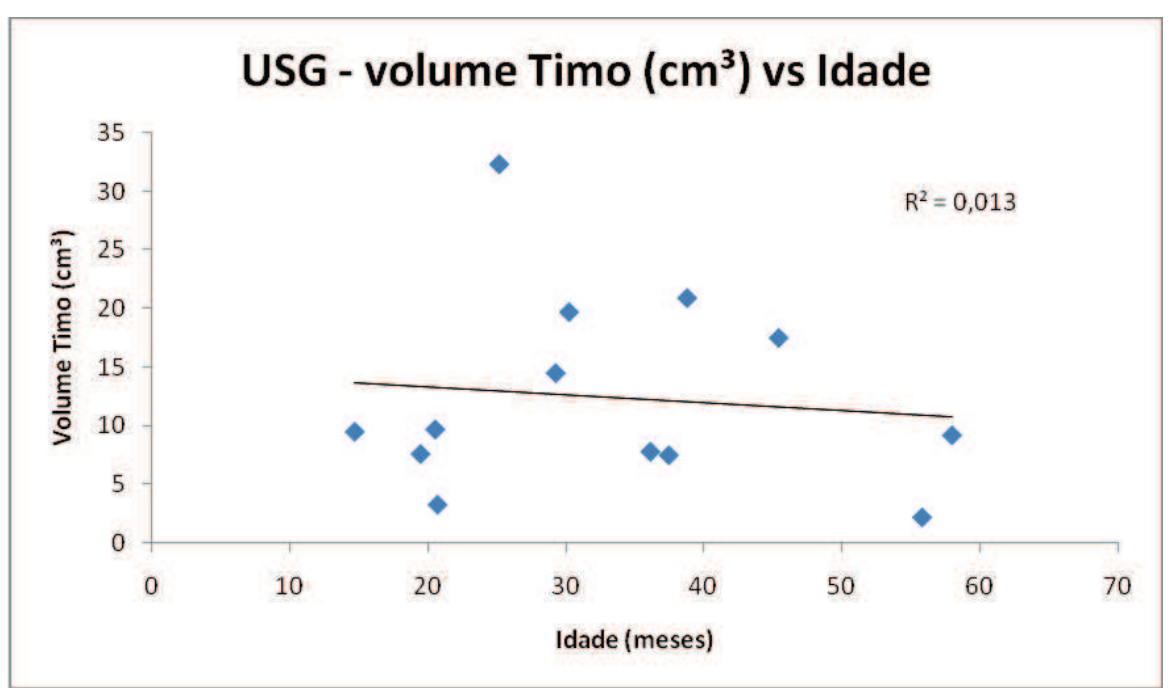

Figura 17 - Correlação de Spearman entre volume do timo e idade (meses) 
Na comparação entre subgrupos 0-24m e 25-60m com os controles de 10 a 20 anos verificamos que os grupos de maior idade apresentam valor inferior de TRECs em relação aos mais jovens. (Figura 18)

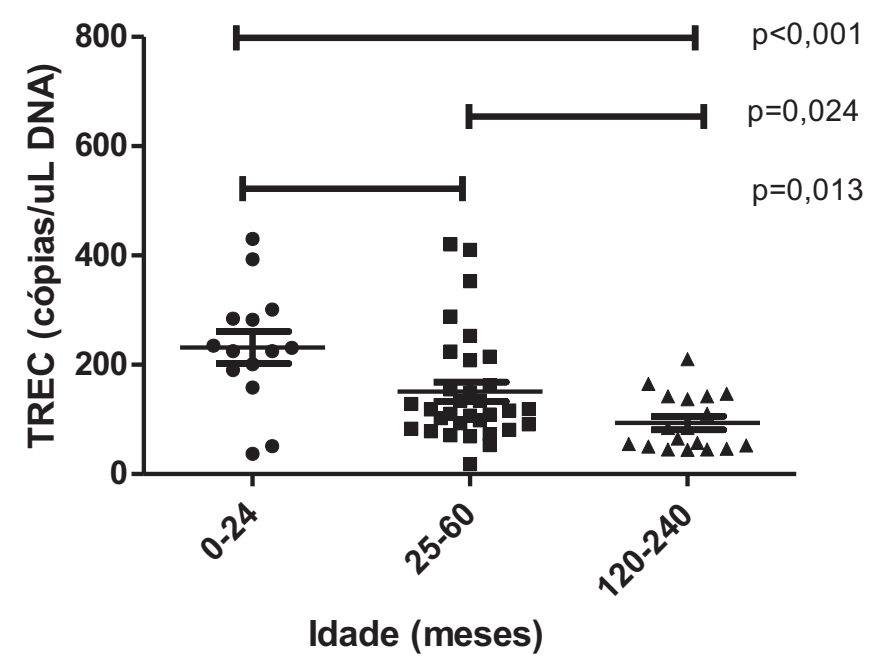

Figura 18 - Comparação de TRECs entre subgrupos 0-24m e 25-60m com os controles de 10 a 20 anos

Quando realizada a análise de correlação entre TREC e idade verificamos uma correlação inversa, com significância estatística. (Figura 19)

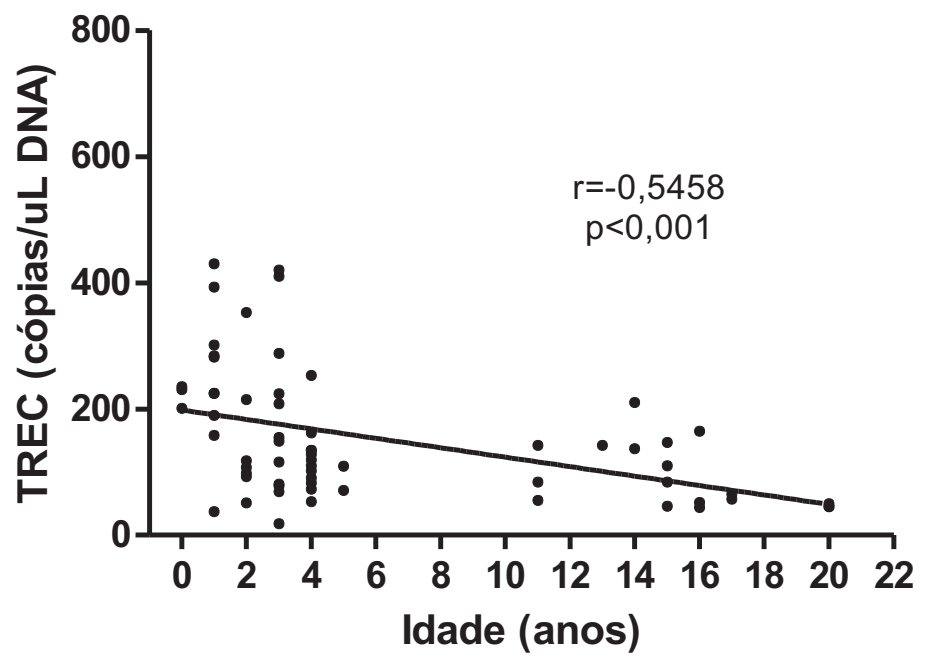

Figura 19 - Correlação de Spearman entre idade e TRECs 
DISCUSSÃO

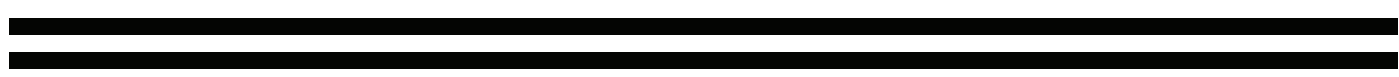




\section{DISCUSSÃO}

Este é um estudo pioneiro na literatura médica sobre avaliação da função do timo e tentativa de correlação com sua morfologia em crianças hígidas de baixa idade. Até onde foi possível levantar na literatura, este é o primeiro estudo de timo por elastografia.

Nossos resultados são preliminares, porém trazem contribuições em dois campos. Primeiramente na implantação da elastografia para uso em medidas de timo e em segundo lugar ampliando o conhecimento sobre concentrações de TRECs em sangue periférico (medida mais utilizada na prática clínica médica), com ênfase nas diferentes faixas etárias em crianças até 5 anos, faixas estas em que o timo tem sua maior importância fisiológica ${ }^{8}$, diferente dos resultados de trabalhos pregressos que tem sua maior casuística em faixas etárias mais altas ${ }^{17,42}$.

O timo tem sua função primordial no período antenatal e nos primeiros anos de vida do indivíduo e talvez por esse motivo, tem sido negligenciado na prática clínica e na literatura médica ${ }^{43}$, 44 Outros órgãos como o fígado, rim e coração, como exemplo, são mais estudados e tem parâmetros melhores estabelecidos para a prática clínica e também para a pesquisa médica. Por esse motivo, e pela dificuldade de acesso a este órgão em razão de sua localização, poucos estudos abordam a importância da função do timo.

A dificuldade de estudos em crianças saudáveis é bem conhecida em razão sobretudo das limitações de ordem ética. Ademais, este o estudo foi realizado num hospital terciário do Estado de São Paulo, referência em atendimento a pacientes com múltiplas comorbidades em um ou mais sistemas orgânicos, onde foi instalado o elastógrafo adquirido com verba FAPESP, o primeiro disponível em hospitais pediátricos no país até o presente momento. Embora o período de estudo tenha sido de 3 anos, a dificuldade de encontrar pacientes hígidos foi muito grande.

Outro fator limitante para explicar a dificuldade na inclusão de pacientes refere-se ao anormal retardo na efetiva entrega do elastógrafo. Na ocasião do 
planejamento do trabalho, o aparelho da elastografia Phillips já estava em processo de compra e que se prolongou por dificuldades burocráticas até julho de 2017, quando iniciou-se a fase de configuração e testes, haja visto que a técnica é pioneira e com dificuldades adicionais de avaliar timo. A licença do Elasti Q da Phillips só foi liberada em junho de 2018 resultando no pequeno número de indivíduos que realizaram a elastografia com IQR adequado.

A elastografia é atualmente um método clínico de avaliação de fibrose hepática em nódulos mamários e de tiróide, assim como para avaliação de nefropatias e hipertensão portal ${ }^{45,46}$.

Em uma busca no Pubmed com os termos MESH: "thymus and elastography and/or ultrassonography", não encontramos nenhum artigo ou estudo, ressaltando o pioneirismo deste trabalho em relação a essa nova técnica, importantíssima por ser indolor e inócua. Essas características ressaltam os valores do Instituto da Criança, considerado um hospital amigo da criança.

A ultrassonografia foi um bom método não invasivo para avaliar a morfologia do timo. Encontramos uma média de 12,43 $\pm 8,33 \mathrm{~cm}^{3}$ estando de acordo com dados da literatura como por exemplo no trabalho de $\operatorname{Varga}^{24}$ de 50 crianças com volume tímico de neonatos masculinos de $13,22 \pm 3,82 \mathrm{~cm}^{3}$. Embora a faixa etária não seja a mesma, Adam et al. mostraram pouco variabilidade do volume tímico em crianças de ambos os sexos até $8 \operatorname{anos}^{47}$. Não pudemos observar correlação do tamanho do timo com idade e tampouco com TRECs conforme autores que nos precederam ${ }^{26,27}$.

A faixa etária compreendida nos permitiu uma janela adequada para avaliação do timo. Para um exame confiável, precisávamos de uma região de interesse (ROI) central e homogênea do timo. Durante o exame, o aparelho nos sinaliza se a região capturada pode ser usada, conforme mapa de cores, baseando-se na homogeneizada dos dados adquiridos naquela janela, fornecendo então um grau de confiabilidade IQR. Se o IQR for menor de 30\%, os dados são confiáveis. O movimento do indivíduo assim como respiração, 
batimento cardiovasculares ou algum artefato que se interpõe entre o transdutor e o timo, interferem no exame. Utilizamos a calibração padronizada de 0-30 kPa ou 0-3,2 m/s pois é o parâmetro clássico utilizado nos exames de elastografia de fígado e também por este ser o menor parâmetro. Em sendo um estudo piloto, averiguamos na prática que este foi efetivamente o melhor pois a média em $\mathrm{m} / \mathrm{s}$ foi ao redor de $1 \mathrm{com}$ desvio padrão de 0,42.

Também optamos pelo transdutor convexo pois era a única opção disponível no momento da compra, não havendo o transdutor linear deste modelo.

Nossa média da elastografia do timo foi de 1,21 $\pm 0,24 \mathrm{~m} / \mathrm{s}$, o que corresponde à elastografia do fígado normal neste aparelho ${ }^{48}$. Apesar da casuística limitada isso corrobora com nossa expectativa do timo ter um tecido com dureza equivalente ao fígado. Como o tecido tímico vai sendo progressivamente substituído por tecido gorduroso com a idade, provavelmente esse índice deverá diminuir com o passar dos anos, hipótese que deve ser validada em um outro estudo. Em esteatose hepática não fibrótica, o índice de elastografia é menor que 1, mostrando que a substituição gordurosa no fígado, também leva a uma diminuição da dureza do tecido ${ }^{(49,50)}$. Em caráter experimental, fizemos a elastografia do timo do próprio autor da tese com 36 anos e hígido, resultando numa elastografia de $0,9 \mathrm{~m} / \mathrm{s}$, corroborando nosso raciocínio.

$\mathrm{Na}$ nossa experiência, as crianças nem sempre ficavam imóveis e tranquilas para o bom andamento do exame. Essa dificuldade era acentuada em crianças abaixo de 2 anos por não cooperarem com ordens verbais do examinador ou dos pais. Neste sentido, algumas crianças não tiveram seu exame concluído, nos levando a crer que esta seja uma das principais limitações desta técnica.

Como não há dados para serem comparados com a literatura, necessitamos de um maior número de exames além de comparar nosso grupo sem comorbidades com um grupo que tenha imunodeficiência $T$ para 
recomendar universalmente o exame, que inócuo e não invasivo, se mostrou promissor na avaliação tímica.

Uma forma consagrada de avaliação da função tímica é representada pelos TRECs, estabelecida no início deste século ${ }^{41}$, porém ainda pouco usada na prática clínica diária para avaliação de agravos a este órgão, que embora frequentes decorrentes do uso de medicação ou infecção são pouco valorizadas.

Seu uso clínico se faz hoje primordialmente em 3 situações:

1. No teste do pezinho. Este exame visa detectar precocemente imunodeficiências T graves. Seu cutoff para detecção é de uma concentração de TRECs menor que $25 \mathrm{pL} / \mathrm{mL}^{20}$.

2. Na reconstituição imunológica para o indivíduo que tenha AIDS e inicie a terapia antirretroviral, onde se faz necessária uma avaliação seriada de TRECs em um mesmo indivíduo, onde o aumento do número se correlaciona com o êxito terapêutico ${ }^{19}$.

3. Na reconstituição no transplante de medula óssea, onde o aumento de TRECs numa análise seriada de um mesmo indivíduo sinaliza boa 'pega' do enxerto 51 .

Nas duas primeiras situações temos um treshold (limite) inferior de TRECs denotando, portanto, ausência ou diminuição de atividade tímica. E na segunda e terceira, temos uma comparação intraindivíduo de melhora de função. Nestas três situações, o uso clínico dos TRECs independe de uma curva de normalidade de TRECs/idade.

No entanto, e apesar do pouco conhecimento, alguns comportamentos do TREC interindivíduos são descritos, como por exemplo a imunoscenecência do timo levando à diminuição do número de TRECs em sangue periférico ${ }^{17}$. Em nossa tese comparamos nosso grupo de indivíduos com controles saudáveis de faixas etárias mais altas, oriundos do banco de TRECs do LIM-36 e demonstramos haver diferença estatística quando 
comparamos os primeiros anos da infância com o grupo da segunda década, como demonstraram autores que nos antecederam ${ }^{17,52}$. Pudemos também observar diferença estatística entre os subgrupos de menores de 5 anos, fato não observado em trabalhos anteriores ao nosso. Trabalhos estes, no entanto, que possuíam casuística menor que a nossa nesta faixa etária.

Embora haja relatos de um número menor de TRECs no sexo masculino na mesma idade comparado ao sexo feminino ${ }^{(53)}$, não pudemos observar diferença intergêneros pois nossa amostragem foi majoritariamente masculina, dado o tipo de cirurgia urológica dos nossos sujeitos. Outros comportamentos do TREC como diminuição por outras agressões como imunodeficiência adquirida ou primária também não foi averiguado por não ter sido objetivo desta tese.

Também não nos foi possível comparar nossos dados com alguns outros na literatura por diferenças nas técnicas de aferição de TRECs. Alguns autores propõem TRECs/linfócitos $T^{54,55}$, outros por número total de células ${ }^{11}$. Nossa escolha foi de número de cópias de TRECs/ $\mu$ g de sangue total pois essa é a técnica já utilizada por nosso laboratório e a mais aceita pela literatura ${ }^{52}$.

Além das variações supracitadas de concentração de TRECs entre indivíduos saudáveis, como idade ${ }^{17}$ e sexo ${ }^{53}$ sabemos dentro de um mesmo organismo, em momentos diferentes, pode haver diferenças de concentração de TRECs como, por exemplo, em agravos infecciosos, autoimunidade ou AIDS $^{51}$. Nestas situações, a rápida multiplicação de células $T$ na periferia diminui o pool de células T näive (portadoras de TRECs) por mecanismos de homeostase de linfócitos T. Ainda existem outras alterações ou agravos que não foram devidamente quantificadas como ciclo circadiano, peso, stress oxidativo e uso de corticosteroides ${ }^{56}$.

Dada a grande variabilidade de concentração de TRECs entre indivíduos ou mesmo intra indivíduo, não conseguimos verificar correlação entre TRECs em sangue total e elastografia tímica medida em $\mathrm{m} / \mathrm{s}$ ou $\mathrm{kPA}$, ou mesmo definir valores de referência por idade. 
Este trabalho traz uma contribuição para o melhor conhecimento da função e da anatomia tímica e espera-se que essa tese estimule colegas pediatras a pensarem que o timo deva ser investigado na infância, principalmente onde ocorrem situações conhecidas de agressão a este órgão tais como quimioterapia, infecções, distúrbios nutricionais e uso prolongado de grandes doses de corticosteroide, entre outras ${ }^{56}$. 
CONCLUSÕES

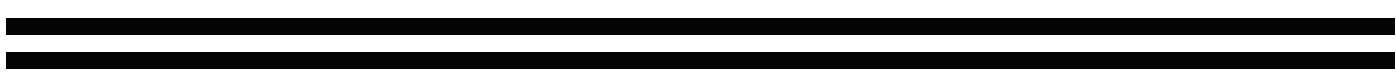




\section{CONCLUSÕES}

- A elastografia é um método inócuo e não invasivo que possibilita a avaliação das dimensões e possivelmente também da função do timo em crianças a partir de 2 anos de idade, entretanto estudos adicionais são necessários para que se possa recomendar a larga implantação deste método com essa finalidade.

- Os valores de TRECs observados mostram uma ampla variabilidade na faixa etária estudada. Comparados com grupo controle de pacientes saudáveis de faixas etárias maiores do LIM-36, observamos valores significativamente mais elevados corroborando a idéia de que o timo tem maior atividade nos primeiros anos de vida.

- Não se encontrou correlação da dureza do timo analisada à elastografia e valores de TRECs em sangue periférico, o que pode ser resultante de um número limitado de casos até o momento estudados e a grande dispersão dos valores de TRECs. 
ANEXOS

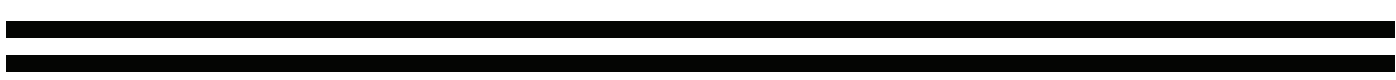




\author{
ANEXO A \\ TERMO DE CONSENTIMENTO LIVRE E ESCLARECIDO
}

\title{
hOSPITAL DAS CLÍNICAS DA FACULDADE DE MEDICINA DA UNIVERSIDADE DE SÃO PAULO-HCFMUSP
}

TERMO DE CONSENTIMENTO LIVRE E ESCLARECIDO

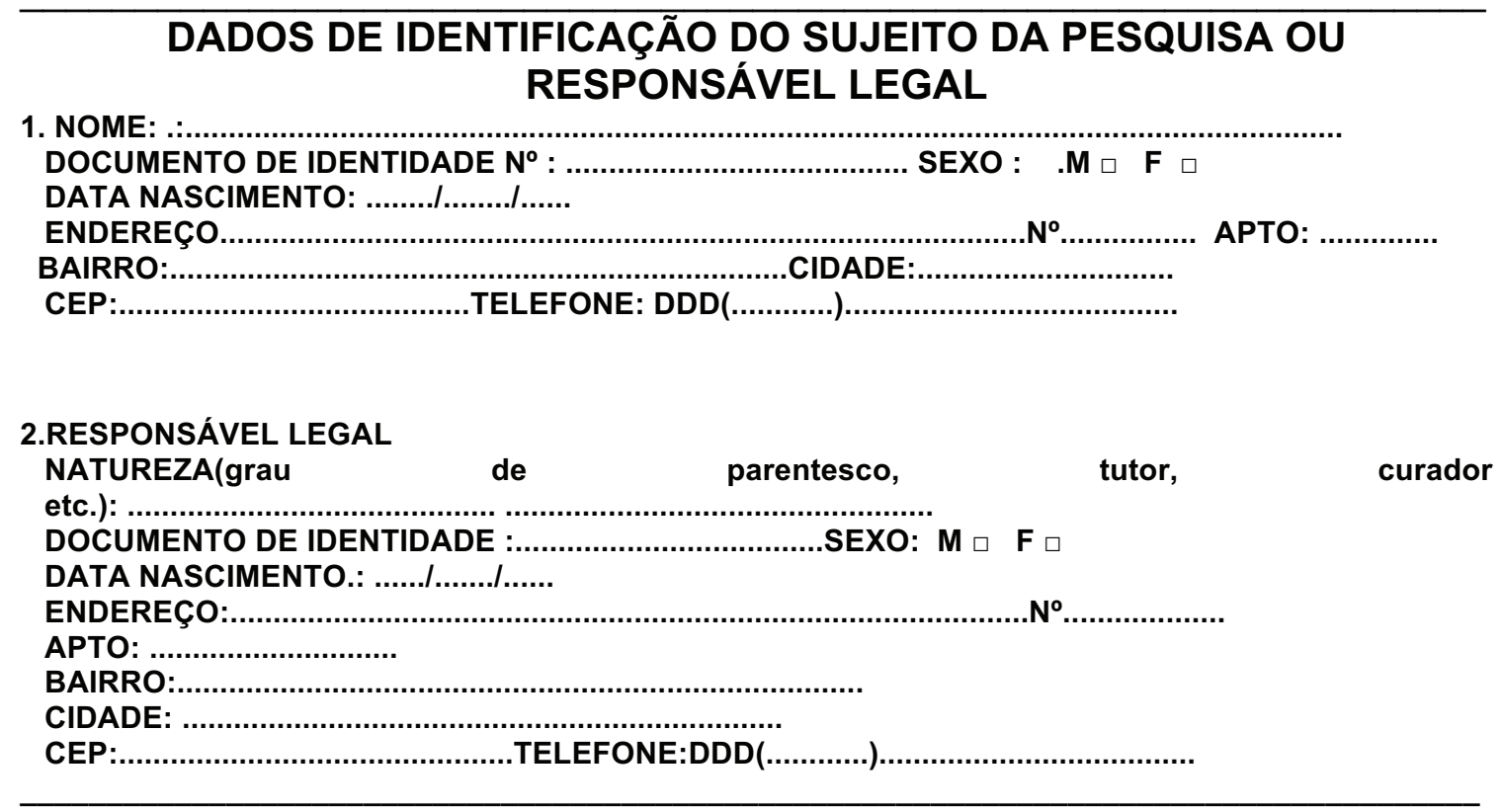

\section{DADOS SOBRE A PESQUISA}

1. TÍTULO DO PROTOCOLO DE PESQUISA: AVALIAÇÃO DA MORFOLOGIA DO TIMO E CONCENTRAÇÃO DE TREC EM SANGUE PERIFÉRICO COMO MARCADORES FUNCIONAIS DO TIMO EM LACTENTES

2. PESQUISADORES : Dr Ariel Levy, Dra. Fernanda Magalhães,Dra. Cristina Jacob.

Pesquisador Executante: Ariel Levy CARGO/FUNÇÃO: Médico INSCRIÇÃO CONSELHO REGIONAL $\mathrm{N}^{\circ}$.126487. Telefone celular: (11) 981581800

UNIDADE DO HCFMUSP: Instituto da Criança

3. AVALIAÇÃO DO RISCO DA PESQUISA:

$\begin{array}{lll}\text { RISCO MÍNIMO } & X \square & \text { RISCO MÉDIO } \\ \text { RISCO BAIXO } & \square & \text { RISCO MAIOR }\end{array}$




\section{HOSPITAL DAS CLÍNICAS DA FACULDADE DE MEDICINA DA UNIVERSIDADE DE SÃO PAULO-HCFMUSP}

1 - Essas informações estão sendo fornecidas para a participação voluntária de seu filho(a) neste estudo, que tem o objetivo de avaliar se o tamanho do timo (que é um órgão do sistema imunológico localizado no tórax) e a quantificação das células do sistema imunológico no sangue periférico, que têm relação com o grau de defesa imunológica (imunidade) de seu filho(a).

2 - A quantidade de sangue utilizada nesta pesquisa é um pequeno volume $(0,3 \mathrm{~mL})$ e seu filho(a) não precisará coletar sangue para isto. Os pesquisadores utilizarão o sangue que sobra após a realização dos exames pedidos pelo médico que atende seu filho(a) no Instituto da Criança, que será enviado para análise das células envolvidas na defesa do organismo. A seguir, seu filho(a) realizará um exame de ultrassom de tórax para medir o tamanho do timo.

3 - Não há riscos no procedimento do ultrassom, havendo, por vezes, incomodo por causa do gel colocado na pele de seu filho. Já em decorrência da coleta de sangue o risco é mínimo decorrente da dor da picada da agulha na veia do antebraço podendo surgir posteriormente uma pequena área de hematoma no local(cor arroxeada). Deve ser ressaltado que a coleta de sangue foi inicialmente solicitada para coleta dos exames de rotina de seu filho e não por causa da pesquisa.

4 - "Não há benefício imediato para seu filho. A pesquisa vai avaliar o potencial dos procedimentos realizados na tentativa de caracterizar o estado de imunidade de seu filho (a)."

5 -Em qualquer etapa do estudo, você terá acesso aos profissionais responsáveis pela pesquisa para esclarecimento de eventuais dúvidas. 0 principal investigador é o $\mathrm{Dr}$.Ariel Levy que pode ser encontrado no endereço: Av. Dr. Enéas Carvalho de Aguiar, 647, São Paulo - SP - Brasil CEP - 05403-000, no $3^{0}$ andar, enfermaria pediátrica. Telefone 26618726 ou celular 981581800 Se 
você tiver alguma consideração ou dúvida sobre a ética da pesquisa, entre em contato com o Comitê de Ética em Pesquisa (CEP) - Rua Ovídio Pires de Campos, 225 - $5^{\circ}$ andar - tel: 2661-6442 ramais 16, 17, 18 - e-mail: cappesq@hcnet.usp.br

6 - É garantida a liberdade da retirada de consentimento a qualquer momento e seu filho pode deixar de participar do estudo sem que isso traga prejuízo ao acompanhamento que ele faz aqui nesta instituição;

7 -As informações obtidas serão analisadas em conjunto com outros pacientes, não sendo divulgado a identificação de nenhum paciente;

8 - Você tem o direito de se informar sobre os resultados parciais da pesquisa, a qualquer momento, podendo para isso procurar qualquer um dos investigadores;

9 - Não há despesas pessoais para o participante em qualquer fase do estudo, incluindo exames e consultas. Também não há compensação financeira relacionada à participação de seu filho(a).

10-Os pesquisadores se comprometem a utilizar os dados e o material coletado somente para esta pesquisa. 


\section{HOSPITAL DAS CLÍNICAS DA FACULDADE DE MEDICINA DA UNIVERSIDADE DE SÃO PAULO-HCFMUSP}

Acredito ter sido suficientemente informado a respeito das informações que li ou que foram lidas para mim, descrevendo o estudo "AVALIAÇÃO DA MORFOLOGIA DO TIMO E DAS CONCENTRAÇÕES DE TREC EM SANGUE PERIFÉRICO COMO MARCADORES FUNCIONAIS DO TIMO EM LACTENTES E CRIANÇAS . EU discuti com o Dr.Ariel Levy sobre a minha decisão em participar nesse estudo. Ficaram claros para mim quais são os propósitos do estudo, os procedimentos a serem realizados, seus desconfortos e riscos, as garantias de confidencialidade e de esclarecimentos permanentes. Ficou claro também que a participação de seu filho(a) é isenta de despesas e que ele(a) tem garantia do acesso a tratamento hospitalar quando necessário. Concordo voluntariamente em que meu filho(a) participe deste estudo e poderei retirar o meu consentimento a qualquer momento, antes ou durante o mesmo, sem penalidades ou prejuízo ou perda de qualquer benefício que meu filho possa ter adquirido, ou no seu atendimento neste Serviço.

Assinatura do paciente/representante legal

Data

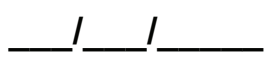

Assinatura da testemunha

Data

para casos de pacientes menores de 18 anos, analfabetos, semi-analfabetos ou portadores de deficiência auditiva ou visual.

Declaro que obtive de forma apropriada e voluntária o Consentimento Livre e Esclarecido deste paciente ou representante legal para a participação neste estudo.

Assinatura do responsável pelo estudo Data 1 


\title{
ANEXO B Aprovação Cappesq
}

\author{
Hospital das Clínicas da FMUSP
}

\section{PROJETO DE PESQUISA}

Título: AVALIAÇÃO DA MORFOLOGIA DO TIMO E DAS CONCENTRAÇÕES DE TREC EM SANGUE PERIFÉRICO COMO MARCADORES FUNCIONAIS DO TIMO EM LACTENTES E CRIANÇAS.

Pesquisador Responsável: CRISTINA MIUKI ABE JACOB

Versão: 2

Pesquisador Executante: ARIEL LEVY

Co-autores: FERNANDA MAGALHÃES, LISA SUZUKI, MAGDA CARNEIRO SAMPAIO

Finalidade Acadêmica Mestrado

Instituição: HCFMUSP

Departamento: PEDIATRIA

\section{PARECER CONSUBSTANCIADO DO CEP}

Registro on-line: 10095

Número do Parecer: 335.543

Data da Relatoria: $17 / 07 / 2013$

Apresentação do Projeto: 0 projeto já havia merecido a aprovação desta Comissão sem restrições.

Objetivo da Pesquisa: Avaliação do potencial da ultrassonografia do timo na determinação de aspectos morfológicos (dimensão e densidade) associado à quantificação de células TREC no sangue periférico de lactentes e crianças até 4 anos como ferramenta útil na avaliação funcional do timo em casos de suspeita diagnóstica de imunodeficiências celulares relacionadas à sua disfunção.

Avaliação dos Riscos e Benefícios: Não há riscos. Não há benefícios imediatos.

Comentários e Considerações sobre a Pesquisa: A relevância do projeto se baseia no estabelecimento do potencial de procedimentos como ultrassom do timo e quantificação de subpopulação TREC de linfócitos T como importantes instrumentos de avaliação funcional desse órgão.

Considerações sobre os Termos de apresentação obrigatória: Os pesquisadores enviaram a versão do TCLE com as alterações solicitadas previamente por esta comissão.

Recomendações: Não há.

Conclusões ou Pendências e Lista de Inadequações: Não há pendências

Situação do Parecer: Aprovado

Necessita Apreciação da CONEP: Não

Considerações Finais a critério do CEP: Em conformidade com o item IX.2 da Resolução CNS no 196/96 cabe ao pesquisador: a) desenvolver o projeto conforme delineado; b) elaborar e apresentar relatórios parciais e final; c)apresentar dados solicitados pelo CEP, a qualquier momento; d) manter em arquivo sob sua guarda, por 5 anos da pesquisa, contendo fichas individuais e todos os demais documentos recomendados pelo CEP; e) encaminhar os resultados para publicação, com os devidos créditos aos pesquisadores associados e ao pessoal técnico participante do projeto; f) justificar perante ao CEP interrupção do projeto ou a não publicação dos resultados.

São Paulo, 18 de Julho de 2013

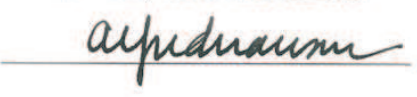

Prof. Dr. Alfredo José Mansur Vice-Coordenador

Comissão de Ética para Anâlise do Projetos de Pequisa - CAPPesq

Rua Dr. Ovídio Pires de Campos, 225 - Prédio da Administração - 50 andar CEP 05403-010 - São Paulo - SP.tnb

5511 2661-7585 - 5511 2661-6442 ramais: 16, 17, 18 | marcia.carvalho@hc.fm.usp.br 
ANEXO C

Aprovação CEP Pediatria - Instituto da Criança

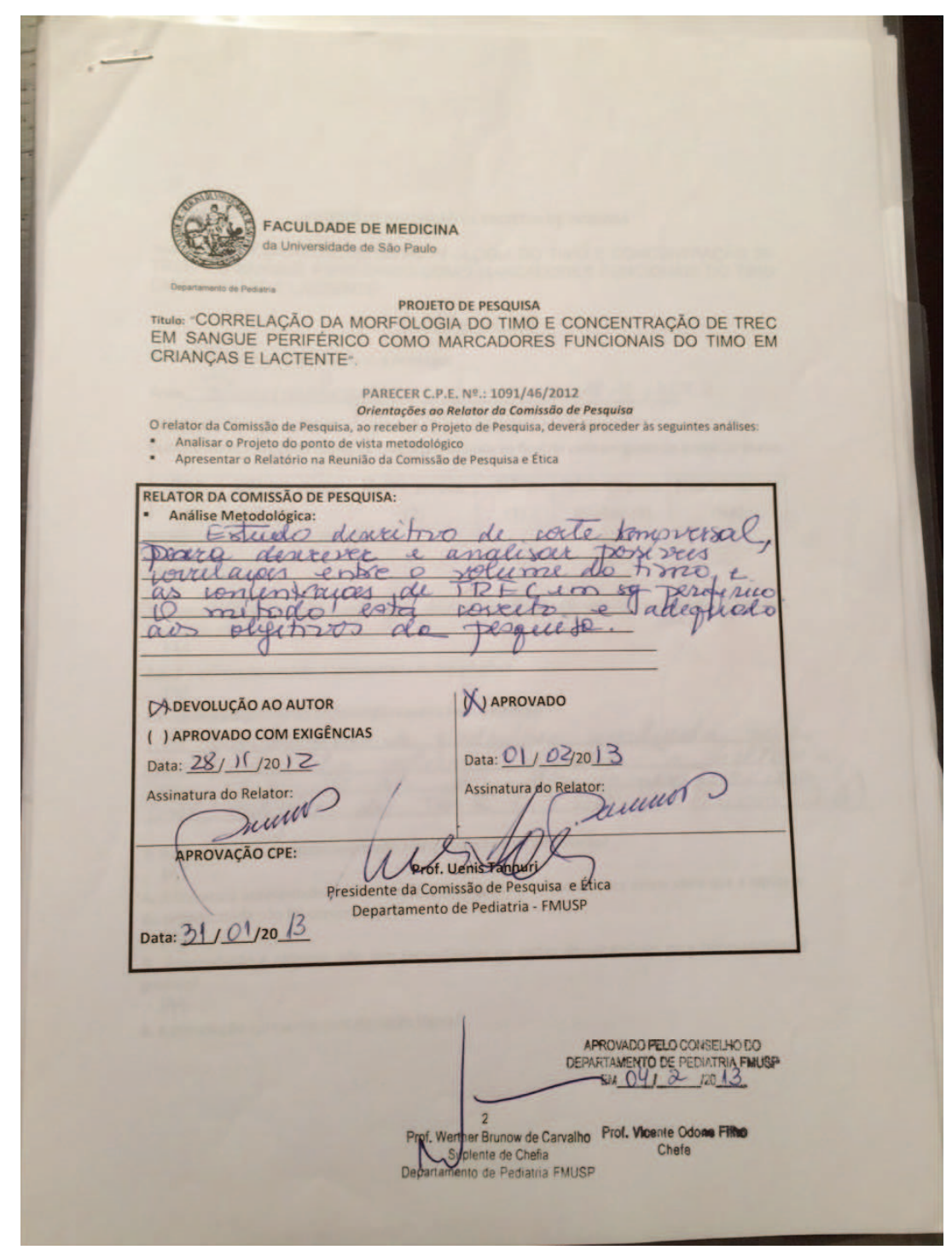


REFERÊNCIAS

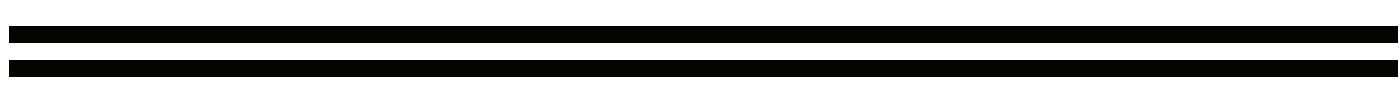




\section{REFERÊNCIAS}

1. Weber EC, Vilensky JA, Carmichael SW, Lee KS. Netter's Concise Radiologic Anatomy; 2010.

2. Al-Herz W, Bousfiha A, Casanova JL, Chatila T, Conley ME, Cunningham-Rundles $\mathrm{C}$, et al. Primary immunodeficiency diseases: an update on the classification from the international union of immunological societies expert committee for primary immunodeficiency. Front Immunol. 2014;5:162.

3. Manley NR, Richie ER, Blackburn CC, Condie BG, Sage J. Structure and function of the thymic microenvironment. Front Biosci (Landmark Ed). 2011 Jun 1;16:2461-77.

4. Lima FA. Estudo da expressão da proteína AIRE (autoimmune regulator) e dos componentes da via de sinalização Notch em timos humanos. Sao Paulo: Universidade de Sao Paulo; 2011.

5. Abbas A, Lichtman A. Imunologia Celular e Molecular Revinter; 2007.

6. Liu D, Ellis H. The mystery of the thymus gland. Clin Anat. 2016 Sep;29(6):679-84.

7. Yan F, Mo X, Liu J, Ye S, Zeng X, Chen D. Thymic function in the regulation of $T$ cells, and molecular mechanisms underlying the modulation of cytokines and stress signaling (Review). Mol Med Rep. 2017 Nov;16(5):717584.

8. Sauce D, Appay V. Altered thymic activity in early life: how does it affect the immune system in young adults? Curr Opin Immunol. 2011 Aug;23(4):543-8.

9. Gregersen PK, Behrens TW. Genetics of autoimmune diseases-disorders of immune homeostasis. Nat Rev Genet. 2006 Dec;7(12):917-28.

10. Castermans E, Morrhaye G, Marchand S, Martens H, Moutschen M, Baron $F$, et al. [Clinical evaluation of thymic function]. Rev Med Liege. 2007 Nov;62(11):675-8. 
11. Douek DC, McFarland RD, Keiser PH, Gage EA, Massey JM, Haynes $\mathrm{BF}$, et al. Changes in thymic function with age and during the treatment of HIV infection. Nature. 1998 Dec 17;396(6712):690-5.

12. Somech R. T-cell receptor excision circles in primary immunodeficiencies and other T-cell immune disorders. Curr Opin Allergy Clin Immunol. 2011 Dec;11(6):517-24.

13. Amariglio N, Lev A, Simon A, Rosenthal E, Spirer Z, Efrati O, et al. Molecular assessment of thymus capabilities in the evaluation of T-cell immunodeficiency. Pediatr Res. 2010 Feb;67(2):211-6.

14. Jamieson BD, Douek DC, Killian S, Hultin LE, Scripture-Adams DD, Giorgi JV, et al. Generation of functional thymocytes in the human adult. Immunity. 1999 May;10(5):569-75.

15. Chan K, Puck JM. Development of population-based newborn screening for severe combined immunodeficiency. J Allergy Clin Immunol. 2005 Feb;115(2):391-8.

16. Steinmann GG. Changes in the human thymus during aging. Curr Top Pathol. 1986;75:43-88.

17. Zhang L, Lewin SR, Markowitz M, Lin HH, Skulsky E, Karanicolas R, et al. Measuring recent thymic emigrants in blood of normal and HIV-1-infected individuals before and after effective therapy. J Exp Med. 1999 Sep 6;190(5):725-32.

18. Prada N, Nasi M, Troiano L, Roat E, Pinti M, Nemes E, et al. Direct analysis of thymic function in children with Down's syndrome. Immun Ageing. 2005;2:4.

19. Ruiz-Mateos E, Rubio A, Vallejo A, De la Rosa R, Sanchez-Quijano A, Lissen $E$, et al. Thymic volume is associated independently with the magnitude of short- and long-term repopulation of CD4+ T cells in HIVinfected adults after highly active antiretroviral therapy (HAART). Clin Exp Immunol. 2004 Jun;136(3):501-6.

20. van der Spek J, Groenwold RH, van der Burg M, van Montfrans JM. TREC Based Newborn Screening for Severe Combined Immunodeficiency Disease: A Systematic Review. J Clin Immunol. 2015 May;35(4):416-30. 
21. Gaballa A, Sundin M, Stikvoort A, Abumaree M, Uzunel M, Sairafi D, et al. T Cell Receptor Excision Circle (TREC) Monitoring after Allogeneic Stem Cell Transplantation; a Predictive Marker for Complications and Clinical Outcome. Int J Mol Sci. 2016 Oct 11;17(10).

22. Adams SP, Kricke S, Ralph E, Gilmour N, Gilmour KC. A comparison of TRECs and flow cytometry for naive T cell quantification. Clin Exp Immunol. 2018 Feb;191(2):198-202.

23. Bodey B, Bodey B, Jr., Siegel SE, Kaiser HE. Involution of the mammalian thymus, one of the leading regulators of aging. In Vivo. 1997 SepOct;11(5):421-40.

24. Varga I, Uhrinova A, Toth F, Mistinova J. Assessment of the thymic morphometry using ultrasound in full-term newborns. Surg Radiol Anat. 2011 Oct;33(8):689-95.

25. Garly ML, Trautner SL, Marx C, Danebod K, Nielsen J, Ravn H, et al. Thymus size at 6 months of age and subsequent child mortality. J Pediatr. 2008 Nov;153(5):683-8, 8 e1-3.

26. Veile A, Winking J, Gurven M, Greaves RD, Kramer KL. Infant growth and the thymus: data from two South American native societies. Am J Hum Biol. 2012 Nov-Dec;24(6):768-75.

27. Kolte L, Rosenfeldt V, Vang L, Jeppesen D, Karlsson I, Ryder LP, et al. Reduced thymic size but no evidence of impaired thymic function in uninfected children born to human immunodeficiency virus-infected mothers. Pediatr Infect Dis J. 2011 Apr;30(4):325-30.

28. Hansen BR, Kolte L, Haugaard SB, Dirksen C, Jensen FK, Ryder LP, et al. Improved thymic index, density and output in HIV-infected patients following low-dose growth hormone therapy: a placebo controlled study. Aids. 2009 Oct 23;23(16):2123-31.

29. Smith KY, Valdez H, Landay A, Spritzler J, Kessler HA, Connick E, et al. Thymic size and lymphocyte restoration in patients with human immunodeficiency virus infection after 48 weeks of zidovudine, lamivudine, and ritonavir therapy. J Infect Dis. 2000 Jan;181(1):141-7. 
30. Haynes BF, Markert ML, Sempowski GD, Patel DD, Hale LP. The role of the thymus in immune reconstitution in aging, bone marrow transplantation, and HIV-1 infection. Annu Rev Immunol. 2000;18:529-60.

31. Ophir J, Cespedes I, Ponnekanti H, Yazdi Y, Li X. Elastography: a quantitative method for imaging the elasticity of biological tissues. Ultrason Imaging. 1991 Apr;13(2):111-34.

32. Hall TJ, Milkowski A, Garra B, Carson P, Palmeri M, Nightingale K, et al. RSNA/QIBA: Shear wave speed as a biomarker for liver fibrosis staging. 2013 Joint UFFC, EFTF and PFM Symposium; 2013.

33. Barr RG. Shear wave liver elastography. Abdom Radiol (NY). 2018 Apr;43(4):800-7.

34. Sarvazyan AP, Skovoroda AR, Emelianov SY, Fowlkes JB, Pipe JG, Adler RS, et al. Biophysical Bases of Elasticity Imaging. Acoustical Imaging. 1995;2:223.

35. Gennisson JL, Deffieux T, Fink M, Tanter M. Ultrasound elastography: principles and techniques. Diagn Interv Imaging. 2013 May;94(5):487-95.

36. Itoh A, Ueno E, Tohno E, Kamma H, Takahashi H, Shiina T, et al. Breast disease: clinical application of US elastography for diagnosis. Radiology. 2006 May;239(2):341-50.

37. Russ G, Royer B, Bigorgne C, Rouxel A, Bienvenu-Perrard M, Leenhardt L. Prospective evaluation of thyroid imaging reporting and data system on 4550 nodules with and without elastography. Eur J Endocrinol. 2013 May;168(5):649-55.

38. Shiina T, Nightingale KR, Palmeri ML, Hall TJ, Bamber JC, Barr RG, et al. WFUMB guidelines and recommendations for clinical use of ultrasound elastography: Part 1: basic principles and terminology. Ultrasound Med Biol. 2015 May;41(5):1126-47.

39. Vejdani-Jahromi M, Freedman J, Trahey GE, Wolf PD. Measuring Intraventricular Pressure Using Ultrasound Elastography. J Ultrasound Med. 2018 Sep 14.

40. Berko NS, Fitzgerald EF, Amaral TD, Payares M, Levin TL. Ultrasound elastography in children: establishing the normal range of muscle elasticity. Pediatr Radiol. 2014 Feb;44(2):158-63. 
41. Douek DC, Vescio RA, Betts MR, Brenchley JM, Hill BJ, Zhang L, et al. Assessment of thymic output in adults after haematopoietic stem-cell transplantation and prediction of T-cell reconstitution. Lancet. 2000 May 27;355(9218):1875-81.

42. Arismendi MI, Kallas EG, Santos BA, Carneiro-Sampaio MM, Kayser

C. Thymopoiesis and regulatory $T$ cells in healthy children and adolescents. Clinics (Sao Paulo). 2012;67(5):425-9.

43. Shanker A. Is thymus redundant after adulthood? Immunol Lett. 2004 Feb 15;91(2-3):79-86.

44. Sempowski G, Thomasch J, Gooding M, Hale L, Edwards L, Ciafaloni $E$, et al. Effect of thymectomy on human peripheral blood $T$ cell pools in myasthenia gravis. J Immunol. 2001 Feb 15;166(4):2808-17.

45. Balleyguier C, Ciolovan L, Ammari S, Canale S, Sethom S, Al Rouhbane $\mathrm{R}$, et al. Breast elastography: the technical process and its applications. Diagn Interv Imaging. 2013 May;94(5):503-13.

46. Monpeyssen H, Tramalloni J, Poiree S, Helenon O, Correas JM. Elastography of the thyroid. Diagn Interv Imaging. 2013 May;94(5):535-44.

47. Adam EJ, Ignotus PI. Sonography of the thymus in healthy children: frequency of visualization, size, and appearance. AJR Am J Roentgenol. 1993 Jul;161(1):153-5.

48. Galina P, Alexopoulou E, Zellos A, Grigoraki V, Siahanidou T, Kelekis NL, et al. Performance of two--dimensional ultrasound shear wave elastography: reference values of normal liver stiffness in children. Pediatr Radiol 2018;Sep 28.

49. Friedrich-Rust M, Wunder K, Kriener S, Sotoudeh F, Richter S, Bojunga J, et al. Liver fibrosis in viral hepatitis: noninvasive assessment with acoustic radiation force impulse imaging versus transient elastography. Radiology. 2009 Aug;252(2):595-604.

50. Dyson JK, McPherson S, Anstee QM. Republished: Non-alcoholic fatty liver disease: non-invasive investigation and risk stratification. Postgrad Med J. 2014 May;90(1063):254-66. 
51. Ye P, Kirschner DE. Reevaluation of $T$ cell receptor excision circles as a measure of human recent thymic emigrants. J Immunol. 2002 May 15;168(10):4968-79.

52. Lorenzi AR, Patterson AM, Pratt A, Jefferson M, Chapman CE, Ponchel $F$, et al. Determination of thymic function directly from peripheral blood: a validated modification to an established method. J Immunol Methods. 2008 Dec 31;339(2):185-94.

53. Pido-Lopez J, Imami N, Aspinall R. Both age and gender affect thymic output: more recent thymic migrants in females than males as they age. Clin Exp Immunol. 2001 Sep;125(3):409-13.

54. Lewin SR, Ribeiro RM, Kaufmann GR, Smith D, Zaunders J, Law M, et al. Dynamics of T cells and TCR excision circles differ after treatment of acute and chronic HIV infection. J Immunol. 2002 Oct 15;169(8):4657-66.

55. De Boer RJ. Estimating the role of thymic output in HIV infection. Curr Opin HIV AIDS. 2006 Jan;1(1):16-21.

56. Hollander GA, Krenger W, Blazar BR. Emerging strategies to boost thymic function. Curr Opin Pharmacol. 2010 Aug;10(4):443-53. 